\title{
Mouse Models of Experimental Glioblastoma
}

\author{
Fang Jin ${ }^{1} \bullet$ Helen J. Jin-Lee ${ }^{1} \bullet$ Aaron J. Johnson ${ }^{1,2,3}$ \\ ${ }^{1}$ Mayo Clinic Department of Immunology, Rochester, MN, USA; ${ }^{2}$ Mayo Clinic \\ Department of Molecular Medicine, Rochester, MN, USA; ${ }^{3}$ Mayo Clinic Department \\ of Neurology, Rochester, MN, USA
}

Author for correspondence: Aaron J. Johnson, Mayo Clinic Department of Immunology, Neurology and Molecular Medicine, Rochester, MN, USA.

Email: Johnson.Aaron2@mayo.edu

Doi: https://doi.org/10.36255/exonpublications.gliomas.2021.chapter2

\begin{abstract}
Glioblastoma is one of the most common malignant brain tumors. It has poor prognosis: the survival rate is $14-15$ months, even with treatment by surgery, radiation, and chemotherapy. To develop more efficacious therapies, it is essential to generate preclinical mouse models that enable mechanistic studies. Multiple murine glioblastoma models have been generated, each with distinct advantages and disadvantages. The traditional Cre-LoxP system specifically targets glioblastoma-related genes but requires extended experimental timelines. CRISPR-Cas9 methods require less time to generate mouse models, yet the offtarget effects lead to variable glioblastoma phenotypes. Transposon-based insertional mutagenesis models can intercept and promote transcription but has strict limitation of insertional transgene size. Allograft cell line injection into immunocompetent mice prevents immune rejection but fails to recapitulate various features of human glioblastoma. Intracranial injection of patient-derived xenograft cell lines into immunocompromised mice preserves features of human glioblastoma but does not allow the study of immune cell function in preclinical immunotherapeutic approaches. Finally, humanized mouse models offer the potential to analyze the human adaptive immune response but not the innate
\end{abstract}

In: Gliomas. Debinski W (Editor). Exon Publications, Brisbane, Australia. ISBN: 978-0-6450017-4-7; Doi: https://doi.org/10.36255/exonpublications.gliomas.2021

Copyright: The Authors.

License: This open access article is licenced under Creative Commons Attribution-NonCommercial 4.0 International (CC BY-NC 4.0) https://creativecommons.org/licenses/by-nc/4.0/ 
immune response. This chapter outlines the major experimental glioblastoma models currently employed and the therapeutic approaches that can be tested.

Keywords: Cre-LoxP glioblastoma model; CRISPR/Cas9 glioblastoma model; mouse models of glioblastoma; transgenic glioblastoma model; transplant glioblastoma model

\section{INTRODUCTION}

In 2016, WHO integrated histological and molecular parameters to define the main gliomas types in place of the previous criteria taking into account only histology (1). Under the new criteria, based on histological features, gliomas are classified into four grades. Grade I is the slow growing, less malignant tumors; grade IV is the rapidly growing, highly malignant tumors (2). Glioblastoma is the most aggressive and invasive undifferentiated tumor type and has been designated Grade IV by WHO $(3,4)$.

Based on the molecular feature of whether there is isocitrate dehydrogenase (IDH) mutation, glioblastomas are mainly classified as IDH-wildtype and IDHmutant $(3,5-7)$. IDH mutant glioblastomas are molecularly, biologically, and clinically different from IDH wild-type ones (5), which is important for glioblastoma biology and heterogeneity $(8,9)$. Clinically, primary glioblastoma cases are more related to IDH-wild type; secondary GBM cases are more related to IDH-mutant type; approximately $75 \%$ of patients with secondary glioblastoma have IDH mutation (10).

Pertaining to molecular gene expression studies, there are three major genetic pathways related to glioblastoma formation: (i) inactivation of the $p 53$ pathways accounts for $87 \%$ of glioblastomas; (ii) inactive retinoblastoma $(R B)$ tumor suppressor pathways account for $77 \%$ of glioblastomas; and (iii) amplification and mutation of receptor tyrosine kinase (RTK) genes and activation of the phosphatidylinositol-3-OH kinase (PI3K) pathways account for 88\% of glioblastomas $(11,12)$.

Finally, in vivo experiments have demonstrated that most GBM tumors exhibit deregulation and mutations of genes in the $p 53, R B$ and RTK/RAS/PI3K pathways (13-16). Clinical therapies targeting these pathways are being developed, but the treatments have not been successful (17-20) due to inefficient blood brain barrier penetration, inter-tumor heterogeneity and other compensatory/redundant signaling pathways. To better understand those pathways and their interplay, there is a need for models that reflect the glioblastoma tumor microenvironment (TME), because current in vitro models are not able to recapitulate this. Traditionally, 2D monolayer cell lines cultured in serum-containing medium do not reflect the heterogeneity of human tumors, and hence do not resemble clinical tumor development. Newer approaches using 3D spheres brain cell culture, such as glioma stem-like cell culture, in serum-free medium can reflect better genetic background of the tumor and maintain some phenotypic heterogeneity. However, long-term culture results in the clonal selection and genetic drift. Furthermore, in vitro cell culture does not model human immune cells. This limits exploration of factors regulating tumor-host interactions and immune control (21-23). 
Therefore, it is essential to have animal models that properly reflect the glioblastoma TME so that the glioblastoma biology can be precisely analyzed, which allows for the evaluation of potential treatments, immune therapies and identifying the therapy targets.

\section{MOUSE MODELS OF GLIOBLASTOMA}

Currently, there are four major strategies for generating glioblastoma mouse models: spontaneous, transgenic, transplant, and humanized (Table 1).

\section{Spontaneous glioblastoma mouse models}

Spontaneous mouse glioblastoma tumors are rare (24). Therefore, setting up the spontaneous glioblastoma mouse model would require a large number of mice to observe. Slye, Holmes and Wells found only 3 spontaneous glioblastomata out of 11,188 mouse brains (25). To increase the efficiency and speed of spontaneous tumor generation, chemical or viral induction methods were used. The first successful induced brain tumor was developed in 1939 with intracranial implantation of 20-methylcholanthrene into $\mathrm{C} 3 \mathrm{H}$ mice subarachnoid by Seligman and Shear, which led to gliomas and meningeal fibrosarcomas (26). Even though chemical-induced glioblastoma models are now outdated, several mouse cell lines established from those tumors have been later used for allograft implantation mouse models (27-31). Rous sarcoma virus has been used to induce mouse glioblastoma since the 1960s (32-34). However, virus-induced tumors had incomplete tumor penetrance $(35,36)$. The special maintenance requirement of the virus and the virus-induced mice dramatically increases the cost. In recent years, engineered viruses as vectors for transgenic genes are now used to generate mouse glioblastoma models. Both retrovirus and lentivirus have been applied this way, as will be discussed in the following section.

\section{Transgenic glioblastoma mouse models}

Currently, the main systems used for transgenic mouse models are the Cre-LoxP system, transposon-based system, CRISPR/cas9 system, and virus vectors delivery system. These systems can be used in both germline and somatic transgenic mice (37). The common goal of generating mouse glioblastoma models is increasing activity through overexpression of oncogenes such as p21-RAS, PI3K, EGFR, CDK4 and MDM2, or decreasing activity by mutating tumor suppressor genes, such as Pten, p53, CDKN2A and RB (34). Generally, germline transgenic mouse models are generated by first introducing defined DNA alterations in germline cells, then using breeding strategies to obtain the gene related to the experiment by serial breeding from the founder mouse $(38,39)$. In somatic transgenic mouse models, tumors are initiated by directly implanting the induced transgenic cells, RNA, sh-RNA or engineered virus vectors into specific brain regions (15, 40-43). In recent years, these techniques have been combined to generate more precisely targeted mouse models for research. Fluorescence protein, luciferase reporter, or other tags such as human influenza hemagglutinin are tagged to the transgenic 


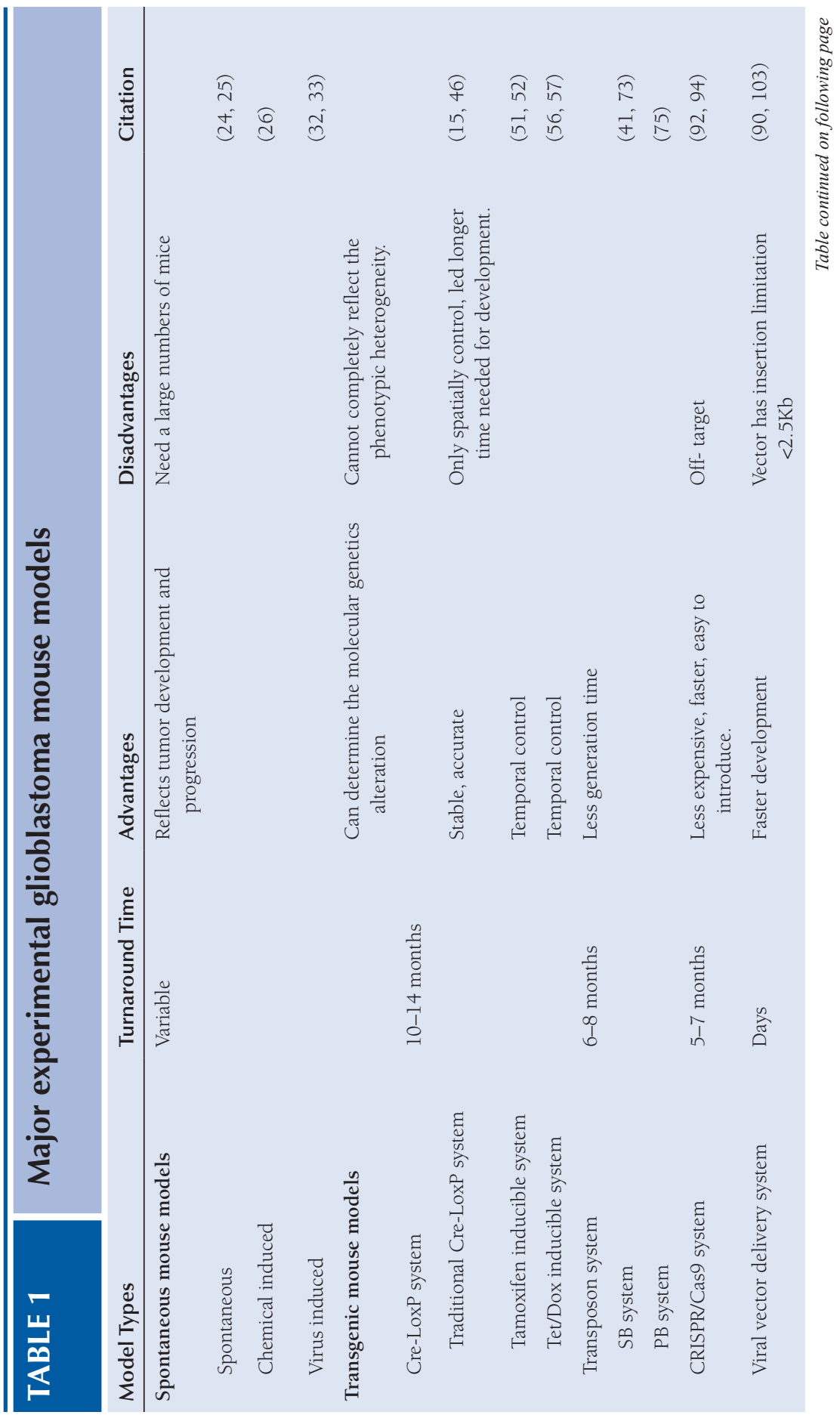




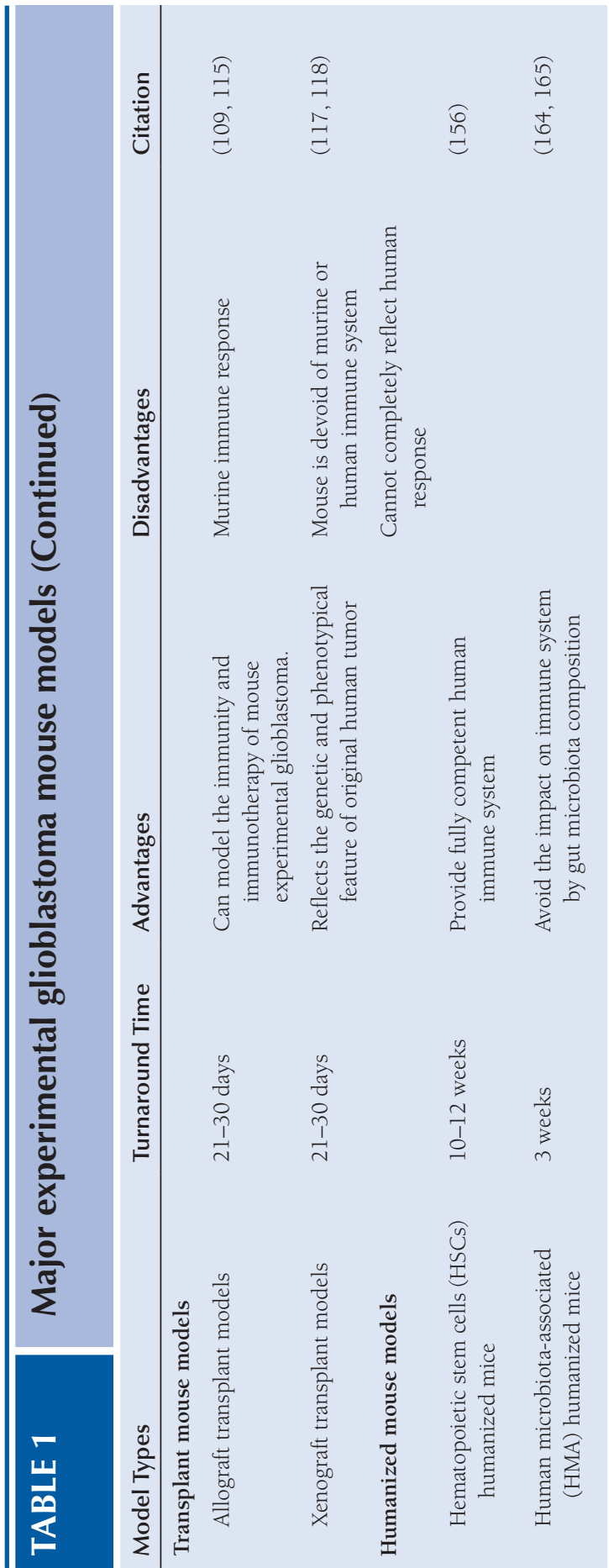


genes so that tracing glioblastoma growth in the mouse models, labeling targeted cells and tissue, and observing microenvironment diffusion and the immune cell response for therapy can be more convenient under the microscope (44).

\section{Cre-LoxP transgenic glioblastoma mouse models}

Most glioblastoma mouse models have used the Cre-LoxP system to target tumor genes in the specific brain tissue of interest (Figure 1A, B) (45). This system provides deep insight into the genetic drivers of glioblastoma and highlights the genetic differences between primary and secondary glioblastomas (13, 15, 46). Previously, most mouse models were generated by breeding two transgenic mice strains: a Cre-driver mouse strain which has Cre recombinase with a promoter and a LoxP floxed mouse strain that has LoxP floxed critical exons of the target gene (Figure 1C) (47). By breeding the two strains together, the system deletes the floxed region and inactivates the gene in desired tissues; the target gene remains functional in all other tissues. On average, it takes 12-18 months to obtain the desired transgenic mice. Therefore, induction of LoxP sites via Cre recombinase viruses_-such as adenovirus and lentivirus_-has been used to shorten the experimental timeline and generate more complex yet easy to obtain transgenic mouse models $(14,15,37,48)$.

Both of the above strategies have been applied in testing p53 and PTEN function in GFAP positive glioblastoma tissues as demonstrated by the following studies. Zheng et al. generated p53 and PTEN double knock-out mice targeted specifically to astrocytes by using GFAP-Cre ${ }^{+}$mice interbred with P53flox/flox Pten flox/+ mice. From these, $66 \%$ of the tumors were anaplastic astrocytomas and 34\% were glioblastomas (13). Their model indicated that the loss of p53 and PTEN would regulate Myc levels and in turn control NSCs self-renewal and differentiation $(13,46)$. Jacques et al. demonstrated another method for generating transgenic mice that target GFAP positive cells: they used adenovirus expressing Cre recombinase (Adeno-Cre or Adeno GFAP-Cre) injected into mice that have conditional alleles flanked by LoxP sites of $R B, p 53$, and PTEN, to ablate RB/p53, RB/p53/PTEN, or PTEN/p53 in adult mice stem/progenitor cells. Their result indicates that initial deletion of $R B / p 53$ or $R B / p 53 / P T E N$ are relevant to glioblastoma pathogenesis, and that $R B$ loss is important in driving the phenotype of primitive neuroectodermal tumors (14). Friedmann-Morvinski et al. performed stereotaxic injection of Creinducible lentiviral vectors shNF1-shp53 or H-RasV12-shp53 into GFAP-Cre mice to induce $p 53$ deficiency in GFAP positive cells such as astrocytes. They identified that loss of NF1 leads to increased RAS mitogenic signaling and increased cell proliferation, while the loss of functional p53 induces genomic instability for glioblastoma tumorigenesis $(15,37)$.

Cre-LoxP has been a popular system for generating transgenic mouse for years, it can only spatially but not temporally control the tumorigenesis (49, 50). In addition, knock-out or overexpression of some critical genes may lead to early embryo lethality $(51,52)$. To overcome this shortcoming and accurately control the timing of tumor generation, traditional Cre-LoxP system has been modified so that it can be temporally induced by exogenous inducer tamoxifen (TAM) or tetracycline/doxycycline (Tet/Dox), making the gene expression transient and reversible $(16,53,54)$. 
A. Cre and LoxP system

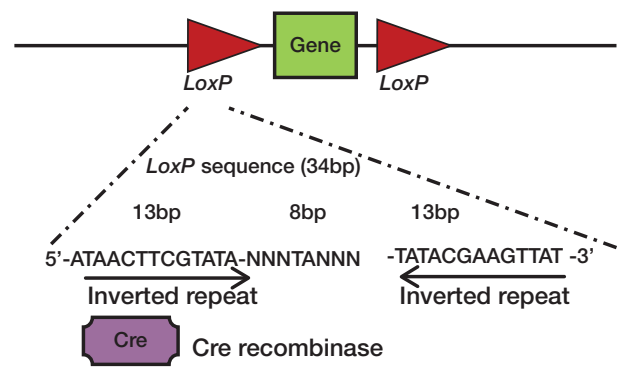

B. General mechanism of Cre-LoxP system

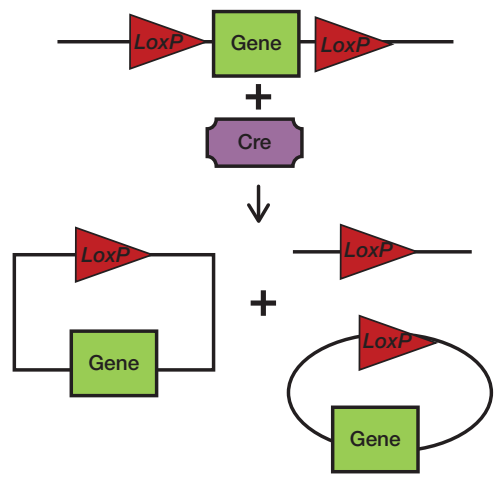

C. Conditional mutant Cre-LoxP mouse generation

Fo

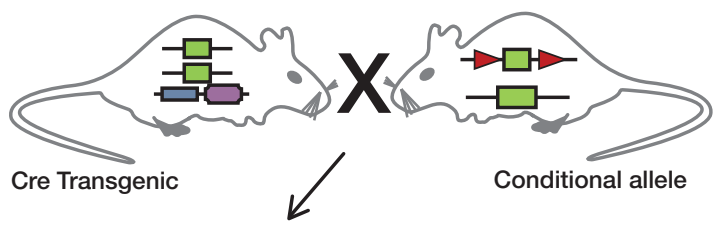

F1

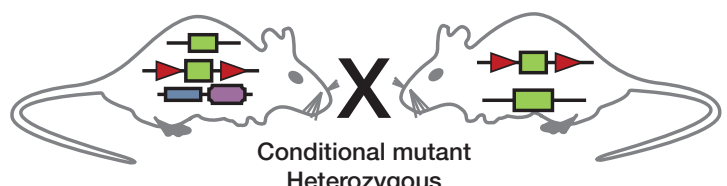
Heterozygous

F2
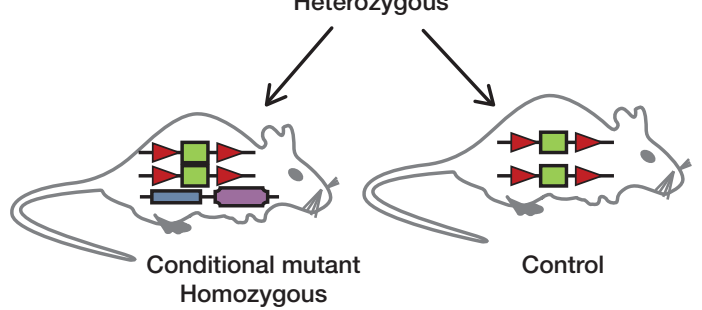

Figure 1. General Cre-LoxP deletion system. (A) Cre and LoxP system; 34-bp LoxP sequence consisting of two 13-bp inverted and palindromic repeats and $8 \mathrm{bp}$ of core sequences; Cre recombinase is a 38-kDa DNA recombinase. (B) General mechanism of Cre-LoxP system; Cre recombinase recognizes the specific DNA fragment sequences between the two repeated LoxP sites and mediates site-specific deletion of DNA to create two pieces of DNA. (C) Traditional Cre-LoxP mouse generation;two strains of mutant mice are bred to generate Cre-LoxP mice: a Cre-driver mouse strain which has Cre recombinase with a promoter, and a LoxP floxed mouse strain that has LoxP floxed critical exons of the target gene; breeding these two strains together generates heterozygous F1 founder mice; F1 mice then breed with LoxP mice again for the F2 homozygotes. 


\section{Inducible Cre-LoxP transgenic glioblastoma mouse models}

There are two widely used inducible Cre-LoxP systems. One is TAM inducible Cre-LoxP system (CreER ${ }^{\mathrm{TM}}$-LoxP system) (Figure $\left.2 \mathrm{~A}, \mathrm{~B}\right)(53)$. Cre recombinase is fused to estrogen receptor (ER) to prevent CreER ${ }^{\mathrm{TM}}$ from entering the nucleus and driving the floxed LoxP sites to delete the target transgenic DNA. When TAM, an ER agonist, is administered into the CreER ${ }^{\mathrm{TM}}$-LoxP system, it binds to the ER and initiates the translocation of CreER into the nucleus, where it can recombine with the floxed LoxP target exon of the DNA. Thus, it can control the timing of gene expression or inactivation and be used to overcome the limitation of Cre-LoxP system where some loss/gain of gene functions would lead to the lethality of mouse in embryo stage or early young $(51,52)$. CreER ${ }^{\mathrm{TM}}$ is Cre recombinase fused to one mutated human ER. This CreER ${ }^{\mathrm{TM}}$-LoxP system needs a higher TAM dosage for induction. To avoid the potential side effects of high TAM levels, $\mathrm{CreER}^{\mathrm{T} 2}$ was generated. It consists of Cre recombinase fused to a triple mutant form of the human ER. Thus, only 1/10 of the TAM dosage required for the CreER ${ }^{\mathrm{TM}}$ system is needed to activate $\mathrm{CreER}^{\mathrm{T} 2}$ (55).

To generate CreER ${ }^{\mathrm{TM}}$-LoxP inducible germline transgenic mouse models, two independent strains of mice are required. One strain expresses CreER ${ }^{\mathrm{TM}}$ controlled by a cell-specific promotor. The other expresses floxed LoxP sites. The two strains of mice are bred together to generate the double transgenic mice. Adding TAM to the mice's food or drinking water permits spatiotemporal control of the target gene expression. This method efficiently avoids early embryos lethality. IDH1 knock-in mice died perinatally if crossed IDH1 $1^{f(R 132 H) /+}$ mice with Nes-Cre mice $(51,52)$. Bardella et al. successfully generated live Nes-CreER ${ }^{\mathrm{T} 2}$; $I D H 1^{f(R 132 H) /+}$ knock-in mice by crossing IDH $f^{f(R 132 H) /+}$ mice with the TAMinducible Nes-CreER ${ }^{\mathrm{T} 2}$ mice. At 5-6 weeks of age, TAM induction was performed for 5 consecutive days to successfully obtain R132H knock-in mice. This mouse model demonstrates that overexpression of IDH1 mutation in mouse brain subventricular zone (SVZ) cells contributed to glioblastoma formation through Myc and Wnt pathways activation, telomere pathway activation, and DNA hypermethylation (51).

The CreER ${ }^{\mathrm{TM}}$-LoxP system is extremely versatile due to the ease of gene expression control it provides. For example, brain progenitor cell specific inducible Cre mice Ascl1-CreER ${ }^{\mathrm{TM}}, \mathrm{NG2}-\mathrm{CreER}^{\mathrm{TM}}$, and Nes-CreER ${ }^{\mathrm{T} 2}$ were crossed with knockout or conditional knock-out NF1, p53, and PTEN mice to generate double transgenic CreER ${ }^{\mathrm{T} 2}$ floxed LoxP mice. Then the mice were induced by TAM at 4-8 weeks of age, and the timely control of NF1, p53, and PTEN knock-out in specific cells expressing Ascl1, NG2, and Nes allowed for identification of central nervous system cell lineages contributing to glioblastoma $(8,54)$.

The other widely used inducible Cre-LoxP system is Tet inducible Cre-LoxP system (Figure 2 C, D). Dox is an analog medicine to Tet. Since Dox is more efficient in controlling the Tet receptor, researchers use Dox more than Tet in this system. Thus, the system is also called the Dox inducible Cre-LoxP system. There are two types of Tet/Dox inducible systems: Tet/Dox-on and Tet/Dox-off, depending on whether the system uses reverse tetracycline-controlled transactivator (rtTA) or tetracycline-controlled transactivator (tTA). In Tet-on systems, addition of Tet induces gene expression. In Tet-off systems, the desired gene is expressed in the absence of Tet $(38,47)$. Both the Tet-on and Tet-off systems are 


\section{General Principle of Tet/Dox system}
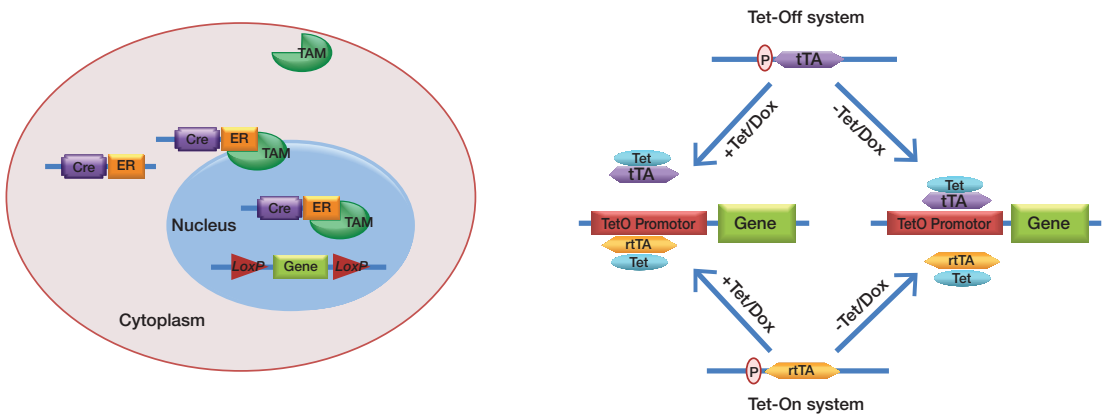

B. TAM inducible mouse model

D. Tet/Dox-off inducible mouse system (tTA)
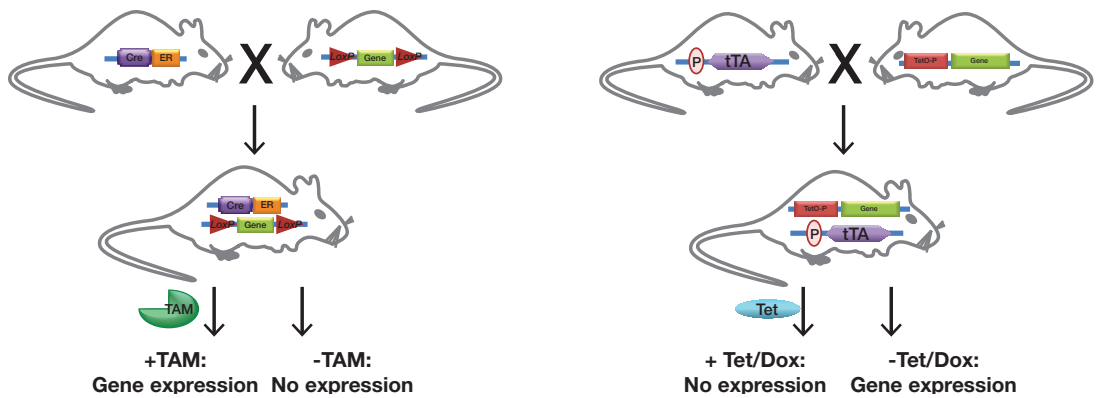

Figure 2. The Cre-LoxP inducible system. A. General Principle of TAM inducible system; in TAM inducible system, Cre is ligated to the ER which stays in the cytoplasm until the administration of TAM; when TAM is administered, CreER binds to the estrogen receptor and initiates the translocation of CreER into the nucleus, where it recombinase with the floxed LoxP target exon of the DNA. B. Tamoxifen inducible mouse model; two independent mouse strains, one strain expressing CreER, the other expressing two LoxP sites with or without a stop code, are bred together to generate double transgenic mice; adding TAM to food or drinking water of the double transgenic mice permits in vivo spatiotemporal control of the target gene expression. C. General principle of Tet/Dox system; two types of Tet/Dox general inducible systems: Tet-on and Tet-off. In Tet-on systems, rtTA is expressed; in the absence of Tet/Dox, inactivated rtTA cannot bind to TetO sequence of Cre gene, so Cre is not expressed; after Tet/Dox administration, activated rtTA binds to TetO promoter of Cre to induce Cre expression, which activates the Cre-LoxP system; In the Tet-off system, tTA is expressed; in the absence of Tet/Dox, activated tTA can bind to TetO sequence of Cre and induce Cre expression; after Tet/Dox administration, tTA is inactivated; inactivated rTA cannot bind to TetO promoter, therefore Cre expression is inhibited. D. Tet/Dox-off inducible mouse system (tTA); two independent strains of transgenic mice are needed: one strain requires tTA expression, the other strain requires the expression of the mutant gene of interest is controlled by TetO promotor with Cre expression; these two strains of mice are bred together to generate double-transgenic mice; by adding Tet/Dox to food or drinking water of the double transgenic mice allows the in vivo target gene to express spatiotemporally. 
used widely to spatiotemporally control tumor generation in transgenic mouse models $(16,40)$.

Similar to the TAM inducible transgenic mouse model, the Tet/Dox inducible model requires two independent strains of transgenic mice. One strain is the transactivator requiring rtTA or tTA expression under the control of a specific promotor. The other is the responder requiring that the expression of the mutant gene of interest is controlled by TetO promotor with Cre expression. These two strains are bred together to generate the desired double-transgenic mice. Then Tet/Dox is added to food or drinking water of the double transgenic mice to allow the target gene to express spatiotemporally $(56,57)$. Although Tet/Dox inducible Cre-LoxP system can flexibly control the timing of transgenic expression, one shortcoming is the leakiness of rtTA, which can result in undesired transcription of the target genes. This is because rtTA has some affinity for TetO sequences even in the absence of Tet (58). In addition, the potential side effects from high doses of Tet/Dox are also unknown. To avoid these limitations, mutagenized rtTA ${ }^{2 S}$ were generated to increase Dox sensitivity, allowing it to function at Dox concentration 10 times lower than rtTA (59).

\section{Transposons-based transgenic glioblastoma mouse models}

Transposons were first identified more than 50 years ago (60). Transposons can move from one genomic location to another through "cut-and-paste" mechanisms (Figure 3 A) $(61,62)$. Sleeping beauty (SB) and PiggyBac (PB) are two widely used transposases that have been successful in establishing functional mutagenesis in vivo and in vitro. SB transposase inserts a transposon into a TA dinucleotide base pair sequence in the recipient DNA, while $\mathrm{PB}$ transposase inserts a transposon into a TTAA dinucleotide base pair sequence (63). PB integration sites are mainly localized near transcriptional start sites (TSSs), CpG islands, and DNaseI hypersensitive sites. In contrast, SB integrations are more randomly distributed, so the $\mathrm{PB}$ system can perform more efficient stable gene transfer than the SB system (64-66). SB and PB transposon systems have been used in both germline and somatic cells of transgenic mice (Figure $3 \mathrm{~B}, \mathrm{C})(45,60,65,67-71)$.

In germline transposon models, two mouse strains, one that expresses the transposase and one that carries transposons with gene trap cassettes are needed to breed the desired mice in multiple generations $(60,69,72)$. For example, Rosa26-LSL-SB11 (SBase) mice which had conditional floxed-stop SB transposase allele knocked in are bred with T2/Onc2,3 mice which had mutant SB transposon to generate heterozygous mice that expressed SB transposase T2/Onc2,3/+; SBase/+. Then these mice interbred to produce homozygotes for later experiments (73).

The transposons model can also be used in the context of somatic cell mouse models. Virus SB transposase system was used to overcome the shortcoming of transient expression of polyethylenimine/plasmid DNA (PEI/DNA) (74). Thus, it was able to deliver shRNA-p53 with seven other combinations to identify the functions of the oncogenes in different glioblastoma formation pathways. This technique enabled rapid production of different genetically engineered mouse strains and sped up the preclinical drug screening for glioblastomas $(70,75,76)$.

The SB/PB transposase system can also avoid embryonic lethality in mice (77). For example, ATRX mutation, together with mutation of $p 53$ and point mutation of histone $\mathrm{H3} .3$ variant, occurred in $31 \%$ of primary glioblastoma in pediatric 


\section{A. General principle}

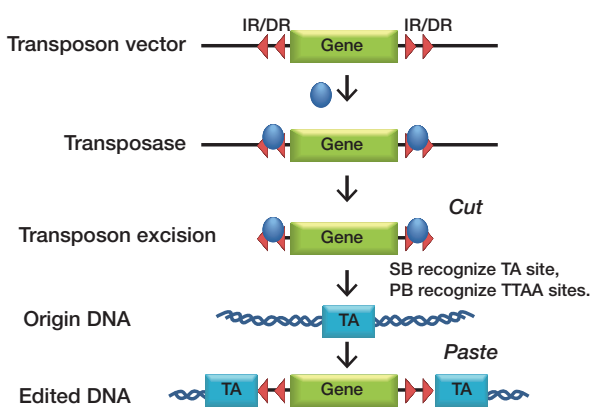

\section{B. Transposons-based somatic transgenic} mouse generation

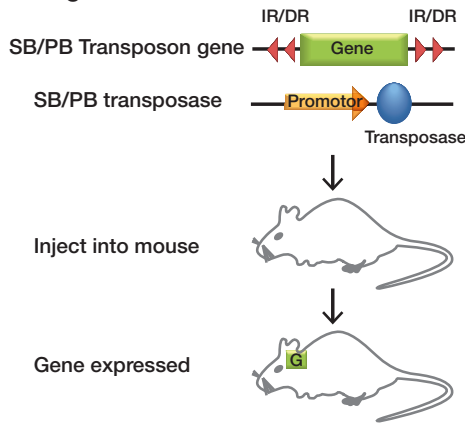

C. Transposons-based germ line transgenic mouse system

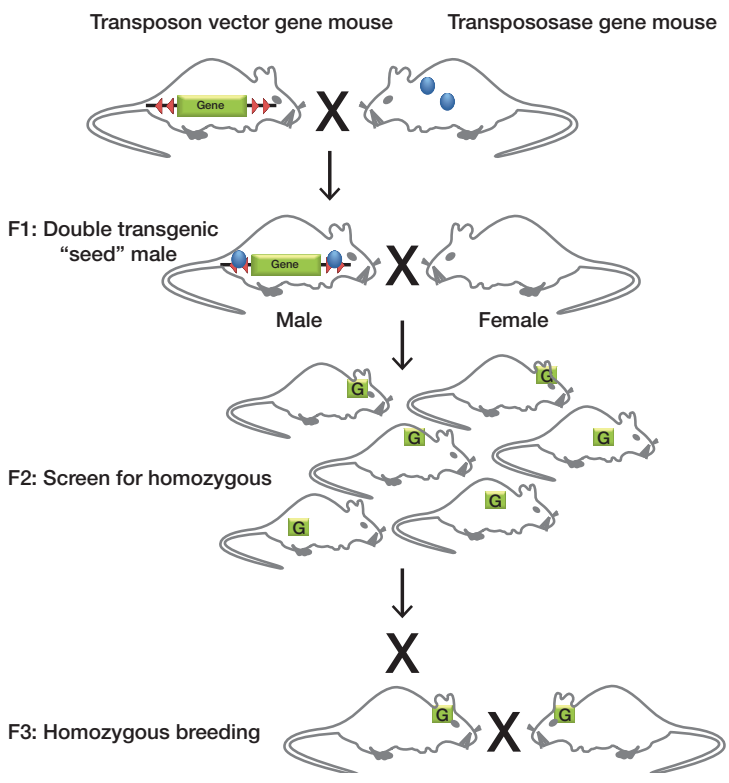

Figure 3. The Transposons-based system. A. General principle of transposon-based system; the transposon-based system includes two parts: a transposon vector containing DNA sequence that is flanked by inverted repeat/direct terminal repeat (IR/DR) sequences, and the transposase enzyme responsible for excision and reintegration of the transposon under the control of a promoter; when transposon vector and transposase are present together, a "cut-and-paste" transposition reaction occurs; the transposon is excised from its original location and re-integrated to a new location within the genome. $S B$ and $P B$ are two different transposases. $S B$ transposase inserts a transposon into a TA dinucleotide base pair sequences, $P B$ transposase inserts a transposon into a TTAA dinucleotide base pair sequences. B. Transposon-based somatic cell transgenic mouse system; to generate the somatic cell transgenic mouse model, two plasmids are injected together into mice to cause mutations in specifically targeted cells; the transposon insertion sites are detected using PCR screening. C. Transposon-based germ line cell transgenic mouse system; to generate the germ line cell transgenic mouse model, two mouse strains are required: one strain carries the transposons vector gene, and the other carries the transposase gene; these two mouse strains are bred to generate the F1 generation of double transgenic mice; F1 males are crossed with wild-type females to segregate the different insertion events in their sperm cells, generating F2 in the process; then the F2 mice are screened to select the ones with the desired mutant allele, and these mice are crossed together to generate F3 homozygous mice. 
patients (78-80). However, knock-out of ATRX resulted in embryonic lethality in mice $(75,77)$; the zygotes never grew beyond the 4-cell stage (75). Koschmann et al. (41) used SB transposase system to develop somatically mutant ATRX in mice to overcome this limitation. They injected combined plasmids encoding SB transposase/firefly luciferase, shRNA-p53, and NRAS, with or without shRNAATRX, into the lateral ventricle of neonatal mice to generate ATRX deficiency, $p 53$ loss, and NRAS overexpression mouse model (41). But Pathania et al. (75) using SB system by combining H3.3 $3^{K 27 M}$-SBase with ATRX/p53 knock-down constructs injected in neonatal mice, could not induce tumor. Then this group injected combined plasmid produced by PBase system: a transposable shRNA against ATRX together with $H 3.3^{\mathrm{K} 2 \mathrm{M}}$, and a plasmid knock-down $p 53$ with CRISP/Cas9, into E12.5-E13.5 embryos to generate the desired mouse model $(75,76)$. In short, both Koschmann and Pathania tried to use SB system to generate glioblastoma models via double knock-out ATRX and p53. Koschmann et al. succeeded through the SB system in neonatal stage, while Pathania et al. failed with the SB system in neonatal stage but succeeded with the PB system in embryo stage. This suggests that the somatic transgenic stage may be more critical for the lethal genes than the choice of method.

In the SB transposon system, there is only $40-50 \%$ chance that the excised transposon integration would occur in the genome. Additionally, because the number of transposons integrated in the genome decreases over time, a large number of transposable elements are required (81). PB demonstrated the highest efficiency and stability in gene transfer $(64,82,83)$. Even though SB insertional mutagenesis system is more random and less efficient, it can integrate transposons up to $10 \mathrm{~kb}$ in size (84), making it capable of delivering around $80 \%$ of human cDNAs (85). In contrast, the PB system can only insert cDNAs approximately $2.4 \mathrm{~kb}$ in size (86).

\section{CRISPR/Cas9 transgenic glioblastoma mouse models}

CRISPR/Cas9 is an RNA guided nuclease which is involved in prokaryotic immune systems (87-89). It has been used extensively to generate cancer models through genetic editing, providing a fast, inexpensive, and simple method to identify and study genetic determinants of cancer. CRISPR/Cas9 mouse models can be generated by injecting Cas9 mRNA with one or multiple single guide RNAs (sgRNA) directly into mouse somatic cells or germline embryos, which creates precise genomic edits at specific loci (Figure 4 A, B) (90). Depending on the type of DNA repair that took place, two kinds of mouse genome modifications will occur: constitutive knock-out tumor suppressor genes through non-homologous end joining and knock-in oncogenes through homologous recombination (91-93). The whole process takes around 2-3 months, which is much faster than the Cre-LoxP system.

Although the CRISPR/Cas9 system can be used in both somatic and germline cells, researchers are more likely to use it to edit somatic cells in transgenic or wild type mice. Plasmids targeting specific genes are first edited by the CRISPR/Cas9 system, then injected into germline transgenic mouse models generated from CreLoxP and other transgenic systems to create more accurate and precise knock-out or knock-in mouse models $(44,92)$. By injecting plasmids modified by the CRISPR/Cas9 system in utero at Embryo stage E13.5 days, researchers generated 


\section{A. General CRISPR/Cas9 System}

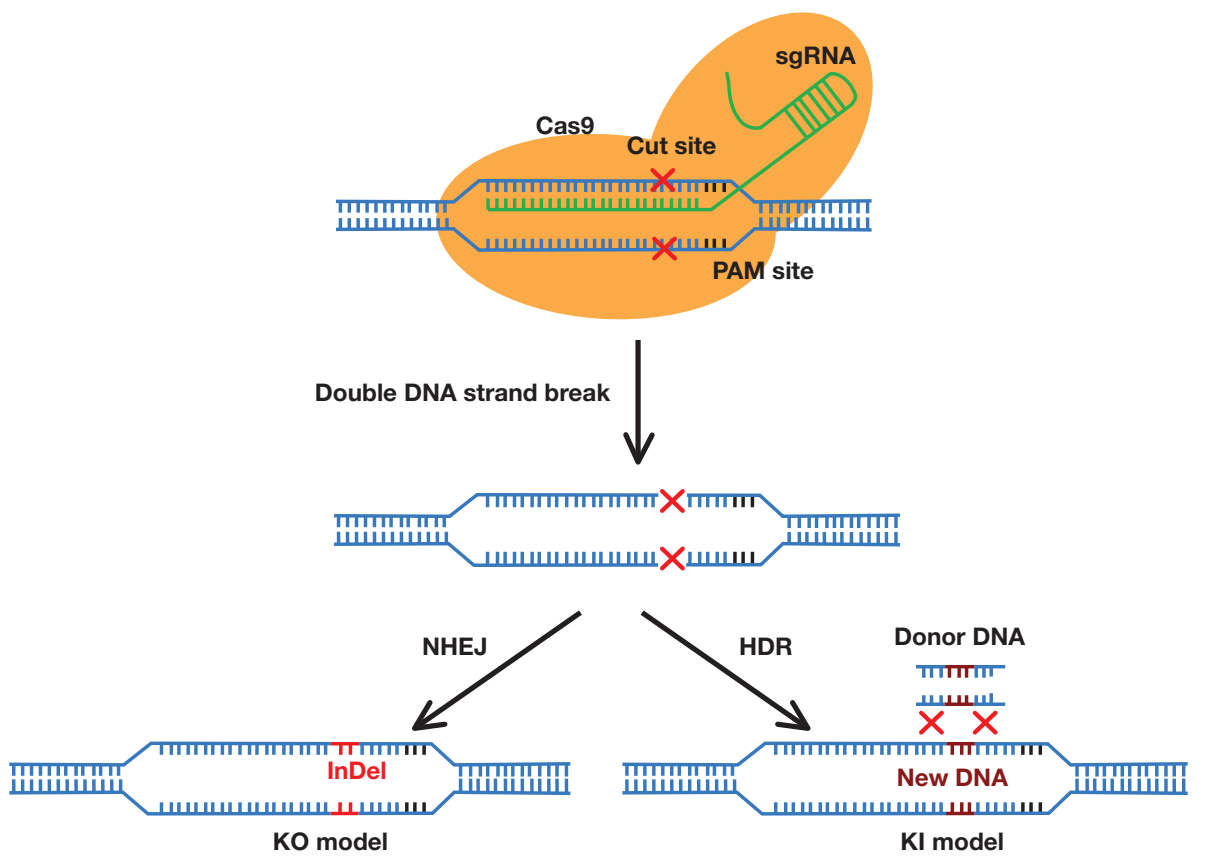

B. CRISPR/Cas9 transgenic mouse model

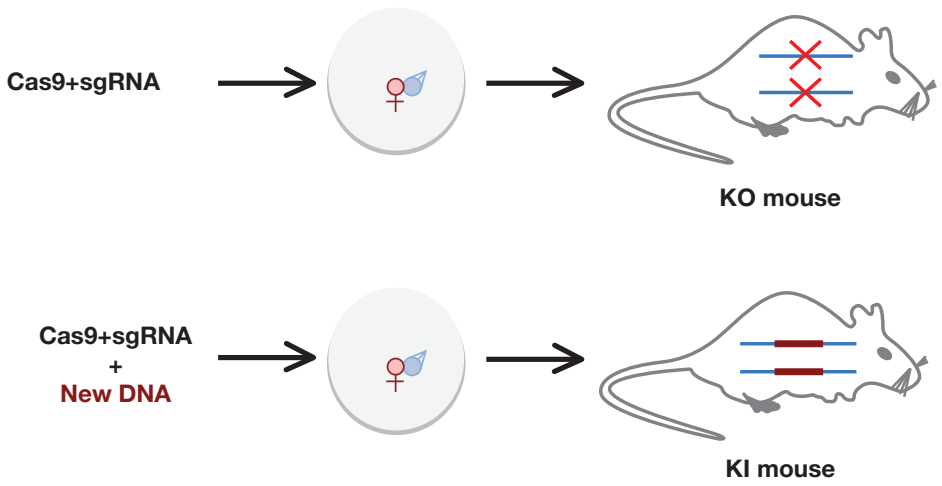

Figure 4. The CRISPR/Cas9 System. A. General CRISPR/Cas9 system; in the general CRISPR/ Cas9 system, Cas9/sgRNA complex recognizes the complementary 20-nucleotide genomic sequence with a downstream protospacer-adjacent motif (PAM) sequence; it cuts three nucleotides upstream of the PAM sequence to induce double-strand DNA breaks (DSBs); the DSBs are then repaired through two major mechanisms: NHEJ pathway which is usually for knock-out genes and HDR pathway which is usually for knock- in genes. B. CRISPR/Cas9 transgenic mouse model; CRISPR/Cas9 germline transgenic mouse models are generated by injecting Cas9 mRNA with one or multiple single guide RNAs (sgRNA) directly into mouse germline embryos; two kinds of mouse genome modifications will occur: constitutive knock-out tumor suppressor genes through NHEJ and knock-in oncogenes through HDR. 
Ptch1, p53 double loss mouse model, instead of using the traditional method of breeding Ptch $^{+/-}$mice with $p 53$-null mice $(92,94)$. The highly aggressive glioma developed in a short period of time in all mice, and the tumors produced via CRISPR/Cas9 are mostly similar to tumors produced in germline transgenic mice (92).

With continued development, gene editing techniques are now used more often in combination for glioblastoma mouse models. Chen et al. combined the CRISPR/Cas9 system and PB transposase lineage labeling to induce somatic mutations in NPCs. They used PB transposase system producing GFP or RFP signal which can label the lineage of CRISPR-targeted progenitors in vivo. At the same time, they used CRISPR/Cas9 constructs containing sgRNAs targeting NF1, PTEN, and $p 53$, alone or in combination to generate NF1, PTEN, and p53 deletion in somatic cells. In this way, they demonstrated that CRISPR/Cas9 combined with PB transposase lineage labeling is a convenient way to produce unique tumors caused by somatic mutation in neural progenitors (44). The CRISPR/Cas9 system is a fast method to provide versatile gene editing, making it extremely useful. However, one major limitation of this nuclease technology is the non-specific and off-target cutting of DNA sequences. Because the Cas9 nuclease randomly cuts within the sequence and can target some slightly different sequences, some undesired mutations may occur, which could significantly affect the phenotype of the generated mouse models (95).

\section{Viral vector delivery system glioblastoma mouse models}

Viral vector delivery is another approach that can modify multiple genes to generate somatic transgenic mouse models $(37,96-98)$. Several types of virus vectors can be used to deliver transgenic or mutant genes, including adenovirus, adeno-associated virus, lentivirus, retrovirus, etc. The main difference between lentiviruses and retroviruses is that lentiviruses are capable of infecting non-dividing and actively dividing cell types, whereas retroviruses can only infect mitotically actively dividing cell types. This means lentiviruses can infect a greater variety of cell types than retroviruses (99). Combining the lentivirus transfection-induced model with targeted conditional knock-out/knock-in transgenic mouse models makes it more convenient to study the pathways that drive glioblastomas $(90,100,101)$. Lentivirus engineered to co-express the TAM induced CreER ${ }^{\mathrm{T} 2}$ along with PDGFB and GFP protein can spatially and temporally control the deletion of the floxed genes in specific cells as well as easily track the transduced cells. The glioblastoma penetrance of this model was as high as $88.5 \%(102)$.

The most widely used retrovirus induction system is the RCAS-TVA delivery system $(42,102)$. This approach uses replication-competent avian sarcomaleukosis retrovirus (RCAS) vectors to target cells that are engineered to express cell surface receptor TVA (a receptor for the avian leukosis viruses (ALV) envelope glycoprotein) (7). RCAS-TVA transgenic mouse models are created by injecting RCAS vectors directly into mouse brain that expresses the RCAS receptor TVA $(90,103,104)$. Combining the RCAS-TVA system with Cre-loxP and other transgenic systems provides a versatile method for producing glioblastoma mouse models containing different types of proliferating cells targeting different tissues (105). To generate glioblastomas, viruses were injected into different locations in 
the brains of wild type mice or mice with various deleted tumor suppressors to overexpress different types of oncogenes in Nes and GFAP positive cells $(43,97,104)$. These studies provided a new way to quickly establish mouse models so that the therapeutic responses of gliomas can be simultaneously compared (97). Glioblastoma mouse models can also be generated by combining RCAS-TVA system with CRISPR-Cas9 transgenic gene editing system to somatically delete tumor suppressor genes p53, Cdk2a, and PTEN in neural stem cells (NSCs) in vivo (90). This RCAS/TVA/Cas9 system is extremely versatile and accurate for somatic gene editing in vivo (90), which can help identify the various tumor-inducing factors of different glioblastoma types. One limitation of the RCAS-TVA system is that it requires the specific TVA-transgenic mouse strains. In addition, RCAS vector has a $2.5 \mathrm{~Kb}$ DNA insert restriction. Genes of larger size cannot be inserted into the RCAS vector (7).

Transgenic mouse models are useful for observing specific genetic alterations involved in glioblastoma initiation and progression, but it is still uncertain whether the gene changes involved in these models truly mirror the tumor progression events in human glioblastomas. Most of the time, transgenic mouse tumors have specific gene mutations in specific cell types such that those tumors are more uniform and cannot completely reflect the phenotypic heterogeneity of human glioblastomas. To accurately reflect the heterogeneity of glioblastomas, mouse models have been created by combining several techniques to generate multiple complex genetic edits. In addition, tumor heterogeneity can also be maintained via transplantation of tumor specimen into mouse models $(44,90,92,97,106)$.

\section{TRANSPLANT GLIOBLASTOMA MOUSE MODELS}

Besides gene ablation mechanisms, immune "escape" mechanisms may also play an important role in glioblastoma development (107). Even if more is known about the gene mutations related to glioblastoma, effective treatment is still difficult due to the microenvironment which can include immune suppressive cells, such as brain microglial and macrophages $(23,108)$. The brain tumor cells can escape from the immune cell surveillance, which facilitates glioblastoma aggression and can potentially induce drug resistance. Thus, understanding the function of the immune system in the glioblastoma microenvironment is most important for developing immune therapy for glioblastomas. Transplant models provide a natural tumor growth environment and have good control over tumor site and size, making them highly reproducible and excellent for tumor immunology studies and preclinical immunotherapy studies.

Transplantation of tumor cells into mice can rapidly generate experimental glioblastoma model for studying tumor biology and examining therapeutic methods. Many types of biological materials can be transplanted into mice brain by intracranial implantation $(31,109)$ or subcutaneous injection (110) techniques. This includes engineered murine tumor cells,such as GL261; engineered virus vaccines; Cre-LoxP, TAM/Tet/Dox induced tumor cells; and cancer cells/tissues from primary patient tumors (PDX). The injection can be done at either embryo stage or post-neonatal stage to induce experimental glioblastoma (7, 109, 111-113). Adult immunocompetent mice fail to tolerate the human-specific tumor 
microenvironment (TME) features, while embryonic (E12.5) mice can be engrafted. The embryonic stage injection induces experimental glioblastoma that invade the mouse brain and exhibit the complex intact TME with vasculature, astrocytes, and immune cell infiltration (111, 114).

There are two types of transplant models: the allograft transplant model, which involves implanting tumor cells from the same species, such as mouse GL261 cell lines implanted into mouse brain $(30,112,115,116)$; and the xenograft transplant model, which involves implanting tumor cells cultured from different species, such as human glioblastoma cell lines implanted into mouse brain $(117,118)$. There are two techniques for the transplantation: stereotactic intracranial injection and subcutaneous injection. Intracranial injection is a more preferable approach used because it directly introduces glioma cells into the brain, where the tumor can develop under the naturally occurring immune environment to model glioblastoma progression and infiltration. Subcutaneous implantation lacks these characteristics (119).

\section{Allograft transplant mouse models}

Allograft transplant mouse models are usually produced in immunocompetent mice, which offers the intact immune system and same tissue context, and thus avoid immune rejection. The cell lines used in allograft mouse model include GL261, GL26, CT-2A, P560, and 4C8. The GL261, GL26, and CT-2A cell lines were generated from carcinogens, including N-ethylnitrosourea and 20-methylcholanthrene induced into C57BL/6 mice. P560 was from spontaneous VM/Dk mouse models. And 4C8 was from B6D2Fl mouse models (120, 121). These cell lines have their own characteristic immune markers that make them suitable for different studies (Table 2) (122-127). Among these cell lines, GL261 is the most widely used for many immunotherapy and gene therapy studies $(128,129)$. This cell line shares several characteristics with human glioblastomas (129-132). Histologically, GL261 tumors show features of ependymoblastoma (130). Immunologically, GL261 expresses high levels of major histocompatibility complex class I (MHC I) as well as MHC II, B7-1, and B7-2, CD31, CXC chemokine receptor 4 (CXCR4) $(129,131)$. Genetically, GL261 shares many gene mutations with human glioblastomas, including RAS oncogene and p53 tumor suppressor gene point mutations $(129,132)$. In general, when $1 \times 10^{5}$ GL261 tumor cells are injected into C57BL/6 mouse brain in 2-4 $\mu$, around 70\% of mice will develop glioblastomas and survive for about 3-4 weeks $(30,109,112)$.

Allograft transplant models have been used to study the immune mechanism for radiation therapy, immune checkpoint therapy, vascular endothelial growth factor (VEGF) therapy and vaccine therapy. Whole brain radiation therapy (WBRT) is one of the therapies tested in the GL261 model. Although WBRT itself has minimal advantage in terms of survival, this approach up-regulates 32 -microglobulin expression in GL261 glioblastomas in vivo and in vitro, thus increasing $\mathrm{CD}^{+} \mathrm{T}$ cell mediated antitumor immune response. When WBRT is combined with vaccine treatment, the long-term survival increased 40-80\% (116). Immune checkpoint anti-PD-1 immunotherapy with radiation is another treatment that showed promise when tested in the GL261 mouse model by inducing activation and expansion in cytotoxic $\mathrm{CD}^{+} \mathrm{T}$ cells. It can also allow the body 


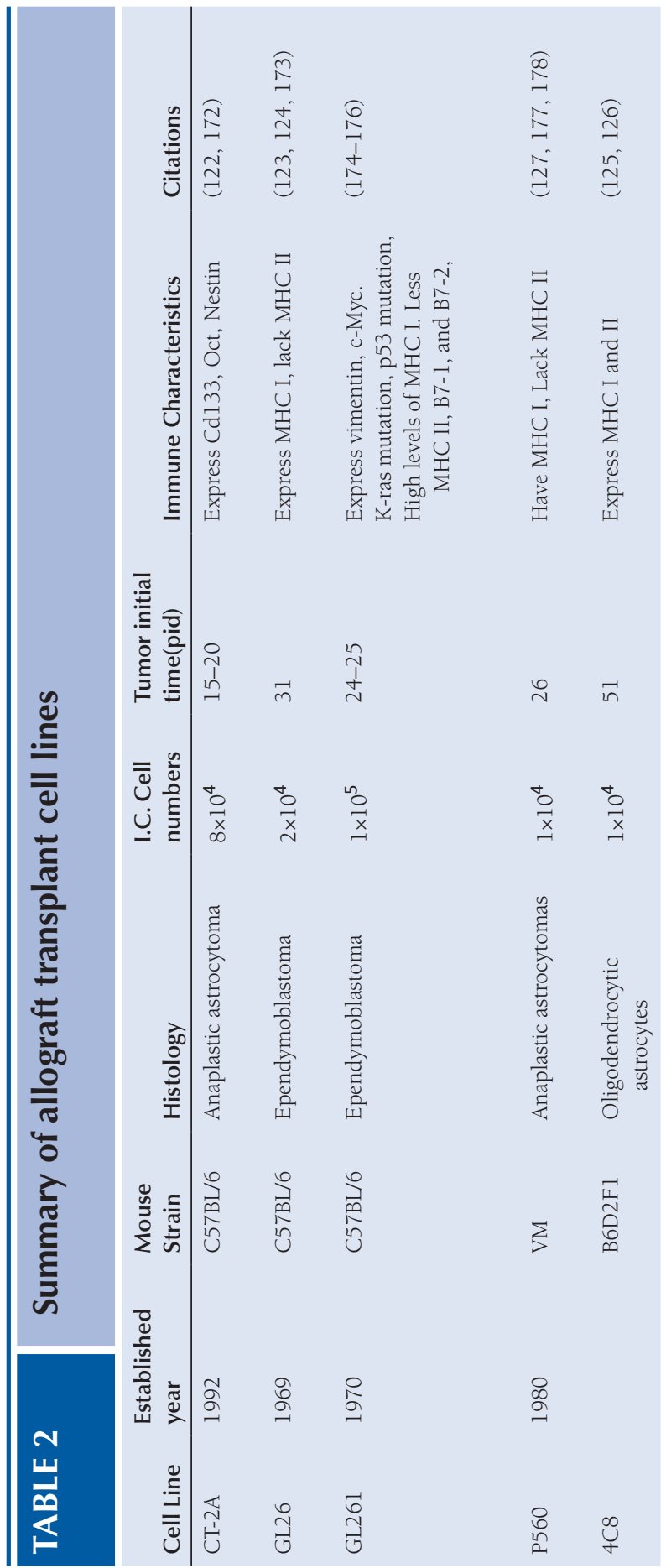


to maintain long-term immunologic memory $(116,133)$. VEGF mediates angiogenesis, and its expression is highly correlated with malignant glioblastoma grade (134). GL261 mouse models have been used to test anti-VEGF combined with vaccination immune therapy. The therapy could significantly delay tumor progression and extend survival period, providing a foundation for further evaluation of the effects of antiangiogenic therapy in the context of endogenous or vaccine-induced inflammatory responses (112).

In addition to wild type C57BL/6J mice, GL261 has also been transplanted into C57BL/6J background transgenic mice to further study the different factors or mutated genes involved in glioblastomas. The Cre-LoxP system has been used to specifically knock-out $\mathrm{H}-2 \mathrm{~K}^{\mathrm{b}}$ or $\mathrm{H}-2 \mathrm{D}^{\mathrm{b}}$ in targeted dendritic cells and macrophages in glioblastoma mouse models to study the role of each cell type in the activation of $\mathrm{CD}^{+} \mathrm{T}$ cells in response to these central nervous system immunological challenges. The role of each cell type in generating the $\mathrm{CD} 8^{+} \mathrm{T}$ cell responses was different. MHC I $\mathrm{H} 2-\mathrm{K}^{\mathrm{b}}$ or $\mathrm{H}-2 \mathrm{D}^{\mathrm{b}}$ antigen presentation by dendritic cells and macrophages in these model systems is non-redundant $(30,31,115)$.

\section{Xenograft transplant glioblastoma mouse models}

Even though mouse GL261 glioblastomas have characteristics highly similar to human glioblastomas, the model cannot replicate the human immune system. Some studies have also shown that the GL261 cell line has genetically drifted and accumulated mutations (135). To reflect the human glioblastoma immune microenvironment, the xenograft transplant mouse model has been established.

Xenograft models are generated by transplanting human glioblastoma cells lines or fresh tissue into immunocompromised mice to induce glioblastomas. Hence this is also called patient-derived xenograft (PDX). This model maintains the genetic and the histological features of the primary tumor from glioblastoma patients. The cell lines or fresh tissue from glioblastoma patients share some similar genetic changes, such as mutation of p53 tumor suppressor gene and PTEN gene, loss of $p 14^{\text {Arf }}$ and $p 16$, and overexpression of AKT due to PI3K/AKT pathway up-regulation $(136,137)$. However, different cell lines or tissues have significant differences in histopathological characteristics. This results in the histology of human glioblastomas being highly variable. Multiple cell lines are being used in xenograft model, such as SF-7761, glioblastomal2, Hs683, etc. $(118,138,139)$. Because the culture conditions in serial generation affect tumor cell phenotype and heterogeneity (140-142), researchers tend to implant freshly isolated tumor cells or tissue fragments without culture or only culturing for a short time $(34,143)$. Injecting fresh human glioblastoma tumor specimen provides the most direct attempt to capture important features of human glioblastoma without any in vitro selection or contact with serum.

Xenograft transplants use immunocompromised mouse strains. The most popular strains are: nude mice, severe combined immunodeficient mice (SCID), non-obese diabetic mice (NOD), non-obese diabetic severe combined immunodeficiency (NOD/SCID), NOD/SCID/interleukin-2 receptor gamma chain (IL2R $)^{\text {null }}$

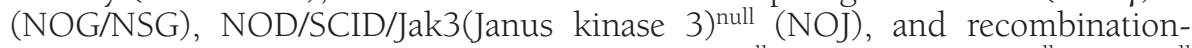
activating gene 2 knock-out serial mice (Rag2 $\left.2^{\text {null }}\right), B A L B / c$ Rag-2 $2^{\text {null }} /$ IL2R $\gamma^{\text {null }}$ (BRG), Rag-2null/Jak3null (BRJ), BALB/c Nude Rag-2/Jak3 (Nude R/J) (Table 3). These strains are deficient in different immune cells, and this incomplete immune 


\section{TABLE 3 Summary of frequently used immunocompromised mice}

\begin{tabular}{|c|c|c|}
\hline Mouse Strain & Full name & Immune Characteristics \\
\hline Nude mice & Athymic nude mice & No thymus, No T cells \\
\hline SCID & Severe Combined Immunodeficient Mice & No T cells, no B cells \\
\hline SCID/Beige & $\begin{array}{l}\text { Severe Combined Immunodeficient Mice/ } \\
\text { Beige }\end{array}$ & $\begin{array}{l}\text { No T cells, no B cells, severe reduced } \\
\text { NK cells }\end{array}$ \\
\hline NOD & Non-obese diabetic mice & $\begin{array}{l}\text { Pancreatic no T cells, impaired NK cells, } \\
\text { macrophages and dendritic cells }\end{array}$ \\
\hline NOD/SCID & $\begin{array}{l}\text { Non-obese diabetic Severe combined } \\
\text { immunodeficiency }\end{array}$ & $\begin{array}{l}\text { No T cells, no B cells, impaired NK cells, } \\
\text { macrophages and dendritic cells }\end{array}$ \\
\hline NOG/NSG & $\begin{array}{l}\text { NOD/SCID/interleukin-2 receptor } \\
\text { gamma chain(IL2R } \gamma)^{\text {null }}\end{array}$ & $\begin{array}{l}\text { No T cells, no B cells, no NK cells, } \\
\text { impaired macrophages and } \\
\text { dendritic cells }\end{array}$ \\
\hline NOJ & NOD/SCID/Jak3(Janus kinase 3) 3ull $^{\text {na }}$ & $\begin{array}{l}\text { No T cells, no B cells, no NK cells, } \\
\text { impaired macrophages and } \\
\text { dendritic cells }\end{array}$ \\
\hline BRG & BALB/c Rag- $2^{\text {null }} / \mathrm{IL} 2 \mathrm{R} \gamma^{\text {null }}$ & No T cells, no B cells, no NK cells \\
\hline BRJ & Rag-2 $2^{\text {null }} / J a k 3^{\text {null }}$ & No T cells, no B cells, no NK cells \\
\hline Nude R/J & BALB/c Nude Rag-2/Jak3 & No T cells, no B cells, no NK cells \\
\hline
\end{tabular}

cell depletion affects the transplant success rate $(144,145)$. Recently, NSG mice have been used more for PDX research because this strain has depleted interleukin-2 (IL-2) receptor gamma. IL-2 receptor gamma signaling pathway is essential for many types of hematopoietic differentiation, so the absence of this receptor causes a dysfunction in innate immunity such as NK cells. These characteristics make NSG mice an effective model for xenograft transplant of primary tumor tissues or cells $(117,146)$.

The mechanism of the many preclinical treatments has been tested using this model. Several human glioblastoma cell lines including wild type $\mathrm{H3.3}$ cell lines (SF9402, SF9427, SF9012 and GBM43) and H3.3 ${ }^{\text {K27M }}$ mutant cell lines (SF8628, SF7761) were transplanted into female athymic nude mice to analyze the effect of GSK J4 treatment for H3.3 ${ }^{K 27 M}$-mutant cell in vivo and in vitro. The results demonstrated that GSKJ4 could reverse $H 3.3^{\mathrm{K} 27 \mathrm{M}}$ demethylation to serve as a therapeutic strategy for lethal pediatric glioblastomas (118). Temozolomide (TMZ), which induces cell cycle arrest at $G_{2} / M$ and eventually leads to apoptosis, is an agent for chemotherapy used to treat glioblastoma $(147,148)$. TMZ is effective for some GBM cell lines in PDX models, such as Hs683 and U87, but not for T98G and $U 373(138,149,150)$. The results obtained across different cell lines, suggest variability in glioblastoma characteristics and their role in responsiveness to TMZ. The mechanism of the viable response is not clear. Some studies showed that the resistance of GBM cell lines to TMZ therapy may due to level of methylated enzyme O6-methylguanine-DNA methyltransferase (MGMT). High levels of 
methylated MGMT promotor showed more response to TMZ (151). But Dr. Egana et al. was not able to demonstrate MGMT methylation could influence patient survival in Glioblastoma. While combining TMZ with bevacizumab, an antiangiogenic antibody targeting VEGF, increased the survival of glioblastoma mice (152).

Xenograft transplant mouse models can preserve the genetic and histological complexity of the primary glioblastomas, but this model differs from patient tumors in many ways. Immunocompromised mice xenograft models do not have an intact immune system and lack the human tumor microenvironment. In addition, a high rate of copy number variations occurs in serial in vivo passaged xenografts, and the murine stroma can also gradually take over $(34,153)$. Xenografts with tissue directly from patients may be better than xenografts with cells that have been expanded in vitro (154), but the differences of immune system between human and immunocompromised mice means that PDX models may not accurately reflect the biological nature of glioblastoma in patients, which is a disadvantage when it comes to preclinical drug studies and chemotherapeutic drug studies. Therefore, it is imperative to find a mouse model that can investigate human glioblastoma development and immunotherapy efficiency in human TME with intact immune system.

\section{Humanized mouse models}

To obtain mouse models with fully competent human immune systems, which enable researchers to examine the interaction between the tumor, immune system, and microbiome for patient preclinical therapy, humanized mice have been generated. These mice have been extensively used for discovering effective immunotherapeutic agents and their combinations (155). Several types of humanized mouse models have been generated, such as PDX human hematopoietic stem cells (HSCs) humanized mice and human microbiota-associated (HMA) humanized mice (156-158). To create PDX HSCs humanized mice, scientists inject human peripheral blood mononuclear cells (hu-PBMCs) or HSCs, or specific HSCs such as Hu-CD34+ HSCs (hu-CD34+) directly into immunodeficient mice after 50-250 cGy whole body irradiation $(117,156)$. The success of the humanization process is that mice have more than $25 \%$ human $\mathrm{CD} 45^{+}$cells in their peripheral blood. Hu-PBMCs mice develop T cells and B cells. It is a model for research on compounds for T cell immune modulation and graft rejection. Hu-CD34+ humanized mice develop almost all human stem cell lines, including $\mathrm{T}$ cells, monocytes, macrophages, mast cells, myeloid (SGM3) cells, NK cells (IL-15), and dendritic cells. It is a more advantageous in vivo model for long-term studies in the fields of human immune cell biology, immuno-oncology, and infectious disease. Jackson lab provides several types of mouse model for different study purposes. The most popular humanized immunocompromised mice strains are NOD. Cg-Prkdc scid Il2rg'tmlWjl Tg(CMV IL-3, CSF2, KITLG)1Eav/MloySzJ (NSG-SGM3), and NOD,B6.SCID $I l 2 \gamma^{-/-} \mathrm{Kit}^{\mathrm{W} 41 / \mathrm{W} 41}$ (NBSGW) mice (NBSGW) (117). NSGSGM3 mice delete IL-2, but express human IL-3, granulocyte-macrophage colony-stimulating factor (GM-CSF) and stem cell factor. These factors enable the stable transplant of human HSCs for humanization (117, 159). NBSGW mice carry c-Kit mutation to support the transplantation of HSCs without irradiation because c-Kit plays a role in cell survival, proliferation, and differentiation (160). A humanized mouse can also be generated by a conditional knock-in/out of a 
specific human gene or a piece of genomic sequence to precisely target a certain tissue, such as SRG-15 mice with knock-in human SIRPA and IL-15 to develop the innate lymphoid cell subsets and NK cells (161); MHC NOG-dKO mice with double knock-out MHC class I and II in NOG mice (162); and NSG-SGM3-BLT mice which involves implanting human fetal liver and thymus fragments as well as hematopoietic stem cells into immunocompromised NSG-SGM3 and NOD/ SCID mice (163).

In addition to the PDX HSCs humanized mice, recently scientists also tried to generate HMA humanized mouse models since research has shown that the gut microbiome is linked to some immune-mediated and metabolic pathologies such as obesity, type 2 diabetes, and cancer (163-166). Recent studies found that balance of commensal microorganisms is important for cancer etiology and that gut microbiota can impact the treatment for cancers (167). Although mouse and human share $85 \%$ similar genomes, they have significant differences in gut microbiota composition. Around $85 \%$ of mouse gut bacteria are not found in human (168). Considering the relationship of gut microbiota composition and cancer development, scientists generated HMA models to avoid the impact on immune system by gut microbiota composition. HMA is established by using microbiota transplantation to transplant human fecal microbiota to germ-free mice (169).

Several studies have used the HMA model $(164,165)$. After successfully establishing the HMA mouse model, GL261 glioma cells were intracranially transplanted to set up glioblastoma HMA model for studying the response to anti-PD-1 or anti-PD-1 combined with TMZ treatments. The mice that survived longer have higher IFN- $\gamma$ and higher $\mathrm{CD}^{+} /$Treg ratio than those that survived shorter. This difference in treatment response was due to the difference in the microbiomes from different patients (164).

Humanized mouse models by themselves or combined with transgenic mouse models highlight a new way to investigate the relationship between glioblastoma development, human immune system, and human microbiota system. It also provides a new platform to study the anticancer immune response for specific immunotherapeutic interventions. However, xenograft PDX humanized mouse models still have challenges due to host innate immune response in immunocompromised mice to the engraft of human cells/tissues, limited lifespan of the mice, incomplete human immune function, and poor lymphoid architecture $(155,170)$. The HMA humanized models also have many biological and technical problems. Whether the human donor microbiomes are successfully transplanted into germ-free mice and whether this model is reproducible still needs confirmation. The mucus properties of germ-free mice are different from conventional mice, which may not completely reflect the human response $(169,171)$. In addition, the transplant procedure may destroy tumor tissue architecture. Therefore, more research is needed to determine whether transplant mouse models are suitable for glioblastoma studies.

\section{CONCLUSION}

Mouse models are extremely useful for studying the biology of glioblastoma. Scientists use mouse models suitable for their experiments to gain insight into mechanisms and factors concerning tumor molecular processes, tumor 
progression microenvironment, and immune and preclinical therapeutics. Spontaneously induced tumors better reflect the natural tumor growth and immune environment change; transgenic mouse systems focus on the targeted genes and pathways for tumor progression; and transplant models are better for tumor immune therapy studies. From Cre-LoxP germline transgenic mouse models to virus vector transgenic somatic transgenic mouse models, many cuttingedge technologies are combined to create combinations of gene mutations that reflect the complexity of glioblastoma in human. This will help in identifying more genotype-specific susceptibilities of human glioblastoma types, manipulating the human glioblastoma epigenome, developing glioblastoma gene therapy and immune therapy in humans, and eventually enabling more personalized, genotype, and phenotype-based treatments for glioblastoma patients in the future.

Conflict of interest: The authors declare no potential conflict of interest with respect to research, authorship and/or publication of this chapter.

Copyright and Permission Statement: The authors confirm that the materials included in this chapter do not violate copyright laws. Where relevant, appropriate permissions have been obtained from the original copyright holder(s), and all original sources have been appropriately acknowledged or referenced.

\section{REFERENCES}

1. Komori T. The 2016 WHO Classification of Tumours of the Central Nervous System: The Major Points of Revision. Neurol Med-Chir. 2017;57(7):301-11. https://doi.org/10.2176/nmc.ra.2017-0010

2. Reifenberger G, Wirsching HG, Knobbe-Thomsen CB, Weller M. Advances in the molecular genetics of gliomas - implications for classification and therapy. Nat Rev Clin Oncol. 2017;14(7):434-52. https://doi.org/10.1038/nrclinonc.2016.204

3. Louis DN, Perry A, Reifenberger G, von Deimling A, Figarella-Branger D, Cavenee WK, et al. The 2016 World Health Organization Classification of Tumors of the Central Nervous System: a summary. Acta Neuropathol. 2016;131(6):803-20. https://doi.org/10.1007/s00401-016-1545-1

4. Hanif F, Muzaffar K, Perveen K, Malhi SM, Simjee Sh U. Glioblastoma Multiforme: A Review of its Epidemiology and Pathogenesis through Clinical Presentation and Treatment. Asian Pac J Cancer Prev. 2017;18(1):3-9.

5. Ceccarelli M, Barthel FP, Malta TM, Sabedot TS, Salama SR, Murray BA, et al. Molecular Profiling Reveals Biologically Discrete Subsets and Pathways of Progression in Diffuse Glioma. Cell. 2016;164(3):550-63. https://doi.org/10.1016/j.cell.2015.12.028

6. Ohgaki H, Kleihues P. The Definition of Primary and Secondary Glioblastoma. Clin Cancer Res. 2013;19(4):764-72. https://doi.org/10.1158/1078-0432.CCR-12-3002

7. Robertson FL, Marques-Torrejon MA, Morrison GM, Pollard SM. Experimental models and tools to tackle glioblastoma. Dis Model Mech. 2019;12(9):1-12. https://doi.org/10.1242/dmm.040386

8. Alcantara Llaguno SR, Wang Z, Sun D, Chen J, Xu J, Kim E, et al. Adult Lineage-Restricted CNS Progenitors Specify Distinct Glioblastoma Subtypes. Cancer Cell. 2015;28(4):429-40. https://doi. org/10.1016/j.ccell.2015.09.007

9. Sutherland KD, Visvader JE. Cellular Mechanisms Underlying Intertumoral Heterogeneity. Trends Cancer. 2015;1(1):15-23. https://doi.org/10.1016/j.trecan.2015.07.003

10. Kloosterhof NK, Bralten LBC, Dubbink HJ, French PJ, van den Bent MJ. Isocitrate dehydrogenase-1 mutations: a fundamentally new understanding of diffuse glioma? Lancet Oncol. 2011;12(1):83-91. https://doi.org/10.1016/S1470-2045(10)70053-X 
11. Aldape K, Zadeh G, Mansouri S, Reifenberger G, von Deimling A. Glioblastoma: pathology, molecular mechanisms and markers. Acta Neuropathol. 2015;129(6):829-48. https://doi.org/10.1007/ s00401-015-1432-1

12. Chin L, Meyerson M, Aldape K, Bigner D, Mikkelsen T, VandenBerg S, et al. Comprehensive genomic characterization defines human glioblastoma genes and core pathways. Nature. 2008;455(7216):1061-8. https://doi.org/10.1038/nature07385

13. Zheng H, Ying H, Yan H, Kimmelman AC, Hiller DJ, Chen AJ, et al. p53 and Pten control neural and glioma stem/progenitor cell renewal and differentiation. Nature. 2008;455(7216):1129-33. https:// doi.org/10.1038/nature07443

14. Jacques TS, Swales A, Brzozowski MJ, Henriquez NV, Linehan JM, Mirzadeh Z, et al. Combinations of genetic mutations in the adult neural stem cell compartment determine brain tumour phenotypes. EMBO J. 2010;29(1):222-35. https://doi.org/10.1038/emboj.2009.327

15. Friedmann-Morvinski D, Bushong EA, Ke E, Soda Y, Marumoto T, Singer O, et al. Dedifferentiation of neurons and astrocytes by oncogenes can induce gliomas in mice. Science. 2012;338(6110):1080-4. https://doi.org/10.1126/science.1226929

16. Arias A, Lame MW, Santarelli L, Hen R, Greene LA, Angelastro JM. Regulated ATF5 loss-of-function in adult mice blocks formation and causes regression/eradication of gliomas. Oncogene. 2012;31(6):739-51. https://doi.org/10.1038/onc.2011.276

17. Arbab AS, Jain M, Achyut BR. p53 Mutation: Critical Mediator of Therapy Resistance against Tumor Microenvironment. Biochem Physiol. 2016;5(3):e153. https://doi.org/10.4172/2168-9652.1000e153

18. Wen PY, Schiff D, Cloughesy TF, Raizer JJ, Laterra J, Smitt M, et al. A phase II study evaluating the efficacy and safety of AMG 102 (rilotumumab) in patients with recurrent glioblastoma. Neuro Oncol. 2011;13(4):437-46. https://doi.org/10.1093/neuonc/noq198

19. Kalpathy-Cramer J, Chandra V, Da X, Ou Y, Emblem KE, Muzikansky A, et al. Phase II study of tivozanib, an oral VEGFR inhibitor, in patients with recurrent glioblastoma. J Neurooncol. 2017;131(3):603-10. https://doi.org/10.1007/s11060-016-2332-5

20. Batchelor TT, Gerstner ER, Ye X, Desideri S, Duda DG, Peereboom D, et al. Feasibility, phase I, and phase II studies of tandutinib, an oral platelet-derived growth factor receptor-beta tyrosine kinase inhibitor, in patients with recurrent glioblastoma. Neuro Oncol. 2017;19(4):567-75. https://doi. org/10.1093/neuonc/nowl85

21. Caragher S, Chalmers AJ, Gomez-Roman N. Glioblastoma's Next Top Model: Novel Culture Systems for Brain Cancer Radiotherapy Research. Cancers. 2019;11(1):44. https://doi.org/10.3390/ cancers 11010044

22. Klein E, Hau AC, Oudin A, Golebiewska A, Niclou SP. Glioblastoma Organoids: Pre-Clinical Applications and Challenges in the Context of Immunotherapy. Front Oncol. 2020;10:604121. https://doi.org/10.3389/fonc.2020.604121

23. DeCordova S, Shastri A, Tsolaki AG, Yasmin H, Klein L, Singh SK, et al. Molecular Heterogeneity and Immunosuppressive Microenvironment in Glioblastoma. Front Immunol. 2020;11:1402. https://doi. org/10.3389/fimmu.2020.01402

24. Houben MP, van Duijn CM, Coebergh JW, Tijssen CC. Gliomas: the role of environmental risk factors and genetic predisposition. Ned Tijdschr Geneeskd. 2005;149(41):2268-72. https://doi. org/10.1016/j.ejca.2005.06.028

25. Slye M HH, Wells HG. Intracranial Neoplasms in Lower Animals: Studies in the Incidence and Inheritability of Spontaneous Tumors in Mice: Twenty-ninth Report. Cancer Res. 1931;15(3):14.

26. Seligman AM, Shear MJ, Alexander L. Studies in Carcinogenesis: VIII. Experimental Production of Brain Tumors in Mice with Methylcholanthrene. Cancer Res. 1939;37(3):364-95.

27. Ausman JI, Shapiro WR, Rall DP. Studies on the Chemotherapy of Experimental Brain Tumors: Development of an Experimental Model. Cancer Res. 1970;30(9):2394-400.

28. Riva M, Wouters R, Weerasekera A, Belderbos S, Nittner D, Thal DR, et al. CT-2A neurospheresderived high-grade glioma in mice: a new model to address tumor stem cells and immunosuppression. Biol Open. 2019;8(9):bio044552. https://doi.org/10.1242/bio.044552

29. Seyfried TN, Elabbadi M, Roy ML. Ganglioside Distribution in Murine Neural Tumors. Mol Chem Neuropathol. 1992;17(2):147-67. https://doi.org/10.1007/BF03159989 
30. Malo CS, Khadka RH, Ayasoufi K, Jin F, AbouChehade JE, Hansen MJ, et al. Immunomodulation Mediated by Anti-angiogenic Therapy Improves CD8 T Cell Immunity Against Experimental Glioma. Front Oncol. 2018;8:320. https://doi.org/10.3389/fonc.2018.00320

31. Tritz ZP, Orozco RC, Malo CS, Ayasoufi K, Fain CE, Khadka RH, et al. Conditional Silencing of H-2D(b) Class I Molecule Expression Modulates the Protective and Pathogenic Kinetics of Virus-AntigenSpecific CD8 T Cell Responses during Theiler's Virus Infection. J Immunol. 2020;205(5):1228-38. https://doi.org/10.4049/jimmunol.2000340

32. Sakamoto K, Hoshino H, Kiuchi Y, Nakano G, Nagamachi Y. Potential Usefullness of a Cultured Glioma Cell-Line Induced by Rous-Sarcoma Virus in B10.A Mouse as an Immunotherapy Model. Jpn J Exp Med. 1989;59(5):173-80.

33. Wilfong RF, Bigner DD, Self DJ, Wechsler W. Brain tumor types induced by the Schmidt-Ruppin strain of Rous sarcoma virus in inbred Fischer rats. Acta Neuropathol. 1973;25(3):196-206. https://doi. org/10.1007/BF00685199

34. Miyai M, Tomita H, Soeda A, Yano H, Iwama T, Hara A. Current trends in mouse models of glioblastoma. J Neuro-Oncol. 2017;135(3):423-32. https://doi.org/10.1007/s11060-017-2626-2

35. Huse JT, Holland EC. Genetically engineered mouse models of brain cancer and the promise of preclinical testing. Brain Pathol. 2009;19(1):132-43. https://doi.org/10.111l/j.1750-3639.2008.00234.x

36. Sonabend AM, Ulasov IV, Lesniak MS. Emerging role of new transgenic mouse models in glioma research. Expert Rev Anticancer Ther. 2007;7(12 Suppl):S7-13. https://doi.org/10.1586/14737140.7.12s.S7

37. Marumoto T, Tashiro A, Friedmann-Morvinski D, Scadeng M, Soda Y, Gage FH, et al. Development of a novel mouse glioma model using lentiviral vectors. Nat Med. 2009;15(1):110-6. https://doi. org/10.1038/nm.1863

38. Tratar UL, Horvat S, Cemazar M. Transgenic Mouse Models in Cancer Research. Front Oncol. 2018;8:268. https://doi.org/10.3389/fonc.2018.00268

39. Hofker MH, Van Deursen JM. Transgenic Mouse Methods and Protocols. 2nd ed. Springer New York Dorrecht Heidelberg London; 2011. Chapter 12, Generating conditional knockout mice; p205-32.

40. Caglayan D, Lundin E, Kastemar M, Westermark B, Ferletta M. Sox21 inhibits glioma progression in vivo by forming complexes with Sox2 and stimulating aberrant differentiation. Int J Cancer. 2013;133(6):1345-56. https://doi.org/10.1002/ijc.28147

41. Koschmann C, Calinescu AA, Nunez FJ, Mackay A, Fazal-Salom J, Thomas D, et al. ATRX loss promotes tumor growth and impairs nonhomologous end joining DNA repair in glioma. Science Translational Medicine. 2016;8(328):328ra28. https://doi.org/10.1126/scitranslmed.aac8228

42. Abounader R. A new practical and versatile mouse model of proneural glioblastoma. Neuro-Oncology. 2018;20(3):299-301. https://doi.org/10.1093/neuonc/nox233

43. Jiang YW, Marinescu VD, Xie Y, Jarvius M, Maturi NP, Haglund C, et al. Glioblastoma Cell Malignancy and Drug Sensitivity Are Affected by the Cell of Origin. Cell Rep. 2017;19(5):1080-1. https://doi. org/10.1016/j.celrep.2017.04.053

44. Chen FY, Rosiene J, Che A, Becker A, LoTurco J. Tracking and transforming neocortical progenitors by CRISPR/Cas9 gene targeting and piggyBac transposase lineage labeling. Development. 2015;142(20):3601-11. https://doi.org/10.1242/dev.118836

45. Noorani I. Genetically Engineered Mouse Models of Gliomas: Technological Developments for Translational Discoveries. Cancers. 2019;11(9):1335. https://doi.org/10.3390/cancers11091335

46. Sears R, Nuckolls F, Haura E, Taya Y, Tamai K, Nevins JR. Multiple Ras-dependent phosphorylation pathways regulate Myc protein stability. Gene Dev. 2000;14(19):2501-14. https://doi.org/10.1101/ gad. 836800

47. Kim H, Kim M, Im SK, Fang S. Mouse Cre-LoxP system: general principles to determine tissue-specific roles of target genes. Lab Anim Res. 2018;34(4):147-59. https://doi.org/10.5625/ lar.2018.34.4.147

48. Zhu H, Acquaviva J, Ramachandran P, Boskovitz A, Woolfenden S, Pfannl R, et al. Oncogenic EGFR signaling cooperates with loss of tumor suppressor gene functions in gliomagenesis. Proc Natl Acad Sci U S A. 2009;106(8):2712-6. https://doi.org/10.1073/pnas.0813314106

49. Macleod KF, Jacks T. Insights into cancer from transgenic mouse models. J Pathol. 1999;187(1):43-60. https://doi.org/10.1002/(SICI)1096-9896(199901)187:1<43::AID-PATH246>3.0.CO;2-P 
50. Talmadge JE, Singh RK, Fidler IJ, Raz A. Murine models to evaluate novel and conventional therapeutic strategies for cancer. Am J Pathol. 2007;170(3):793-804. https://doi.org/10.2353/ ajpath.2007.060929

51. Bardella C, Al-Dalahmah O, Krell D, Brazauskas P, Al-Qahtani K, Tomkova M, et al. Expression of Idhl(R132H) in the Murine Subventricular Zone Stem Cell Niche Recapitulates Features of Early Gliomagenesis. Cancer Cell. 2016;30(4):578-94. https://doi.org/10.1016/j.ccell.2016.08.017

52. Sasaki M, Knobbe CB, Itsumi M, Elia AJ, Harris IS, Chio IIC, et al. D-2-hydroxyglutarate produced by mutant IDH1 perturbs collagen maturation and basement membrane function. Gene Dev. 2012;26(18):2038-49. https://doi.org/10.1101/gad.198200.112

53. Alvarez-Aznar A, Martinez-Corral I, Daubel N, Betsholtz C, Makinen T, Gaengel K. Tamoxifenindependent recombination of reporter genes limits lineage tracing and mosaic analysis using CreER(T2) lines. Transgenic Res. 2020;29(1):53-68. https://doi.org/10.1007/s11248-019-00177-8

54. Alcantara Llaguno S, Chen J, Kwon CH, Jackson EL, Li Y, Burns DK, et al. Malignant astrocytomas originate from neural stem/progenitor cells in a somatic tumor suppressor mouse model. Cancer Cell. 2009;15(1):45-56. https://doi.org/10.1016/j.ccr.2008.12.006

55. Indra AK, Warot X, Brocard J, Bornert JM, Xiao JH, Chambon P, et al. Temporally-controlled sitespecific mutagenesis in the basal layer of the epidermis: comparison of the recombinase activity of the tamoxifen-inducible Cre-ERT and Cre-ERT2 recombinases. Nucleic Acids Res. 1999;27(22):4324-7. https://doi.org/10.1093/nar/27.22.4324

56. Jaisser F. Inducible gene expression and gene modification in transgenic mice. J Am Soc Nephrol. 2000;11(11):S95-S100.

57. Sun Y, Chen X, Xiao D. Tetracycline-inducible expression systems: new strategies and practices in the transgenic mouse modeling. Acta Biochim Biophys Sin (Shanghai). 2007;39(4):235-46. https://doi. org/10.111l/j.1745-7270.2007.00258.x

58. Roney IJ, Rudner AD, Couture JF, Kaern M. Improvement of the reverse tetracycline transactivator by single amino acid substitutions that reduce leaky target gene expression to undetectable levels. Sci Rep. 2016;6:27697. https://doi.org/10.1038/srep27697

59. Osorio L, Long F, Zhou ZJ. Uncovering the stem cell hierarchy by genetic lineage tracing in the mammary gland. Aims Genet. 2016;3(2):130-45. https://doi.org/10.3934/genet.2016.2.130

60. Leslie A. Pray. Transposons: The Jumping Genes. Nature Education. 2008;1(1):204.

61. Plasterk RHA, Izsvak Z, Ivics Z. Resident aliens - the Tcl/mariner superfamily of transposable elements. Trends Genet. 1999;15(8):326-32. https://doi.org/10.1016/S0168-9525(99)01777-1

62. Ivics Z, Hackett PB, Plasterk RH, Izsvak Z. Molecular reconstruction of Sleeping beauty, a Tcl-like transposon from fish, and its transposition in human cells. Cell. 1997;91(4):501-10. https://doi. org/10.1016/S0092-8674(00)80436-5

63. Keng VW, Yae K, Hayakawa T, Mizuno S, Uno Y, Yusa K, et al. Region-specific saturation germline mutagenesis in mice using the Sleeping Beauty transposon system. Nat Methods. 2005;2(10):763-9. https://doi.org/10.1038/nmeth795

64. Huang X, Guo H, Tammana S, Jung YC, Mellgren E, Bassi P, et al. Gene transfer efficiency and genomewide integration profiling of Sleeping Beauty, Tol2, and piggyBac transposons in human primary T cells. Mol Ther. 2010;18(10):1803-13. https://doi.org/10.1038/mt.2010.141

65. Tschida BR, Largaespada DA, Keng VW. Mouse models of cancer: Sleeping Beauty transposons for insertional mutagenesis screens and reverse genetic studies. Semin Cell Dev Biol. 2014;27:86-95. https://doi.org/10.1016/j.semcdb.2014.01.006

66. Calinescu AA, Nunez FJ, Koschmann C, Kolb BL, Lowenstein PR, Castro MG. Transposon Mediated Integration of Plasmid DNA into the Subventricular Zone of Neonatal Mice to Generate Novel Models of Glioblastoma. Jove-J Vis Exp. 2015(96):52443. https://doi.org/10.3791/52443

67. Collier LS, Carlson CM, Ravimohan S, Dupuy AJ, Largaespada DA. Cancer gene discovery in solid tumours using transposon-based somatic mutagenesis in the mouse. Nature. 2005;436(7048):272-6. https://doi.org/10.1038/nature03681

68. Dupuy AJ, Akagi K, Largaespada DA, Copeland NG, Jenkins NA. Mammalian mutagenesis using a highly mobile somatic Sleeping Beauty transposon system. Nature. 2005;436(7048):221-6. https:// doi.org/10.1038/nature03691 
69. Takeda J, Izsvak Z, Ivics Z. Insertional mutagenesis of the mouse germline with Sleeping Beauty transposition. Methods Mol Biol. 2008;435:109-25. https://doi.org/10.1007/978-1-59745-232-8_8

70. Wiesner SM, Decker SA, Larson JD, Ericson K, Forster C, Gallardo JL, et al. De novo Induction of Genetically Engineered Brain Tumors in Mice Using Plasmid DNA. Cancer Res. 2009;69(2):431-9. https://doi.org/10.1158/0008-5472.CAN-08-1800

71. Loeb KR, Hughes BT, Fissel BM, Osteen NJ, Knoblaugh SE, Grim JE, et al. Insertional mutagenesis using the Sleeping Beauty transposon system identifies drivers of erythroleukemia in mice. Sci Rep. 2019;9:5488. https://doi.org/10.1038/s41598-019-41805-x

72. Ivics Z, Li MA, Mates L, Boeke JD, Nagy A, Bradley A, et al. Transposon-mediated genome manipulation in vertebrates (vol 6, pg 415, 2009). Nat Methods. 2009;6(7):415-22. https://doi.org/10.1038/ nmeth.1332

73. Koso H, Takeda H, Yew CCK, Ward JM, Nariai N, Ueno K, et al. Transposon mutagenesis identifies genes that transform neural stem cells into glioma-initiating cells. P Natl Acad Sci USA. 2012;109(44):E2998-E3007. https://doi.org/10.1073/pnas.1215899109

74. Ohlfest JR, Demorest ZL, Motooka Y, Vengco I, Oh S, Chen E, et al. Combinatorial antiangiogenic gene therapy by nonviral gene transfer using the Sleeping Beauty transposon causes tumor regression and improves survival in mice bearing intracranial human glioblastoma. Mol Ther. 2005;12(5):778-88. https://doi.org/10.1016/j.ymthe.2005.07.689

75. Pathania M, De Jay N, Maestro N, Harutyunyan AS, Nitarska J, Pahlavan P, et al. H3.3(K27M) Cooperates with Trp53 Loss and PDGFRA Gain in Mouse Embryonic Neural Progenitor Cells to Induce Invasive High-Grade Gliomas. Cancer Cell. 2017;32(5):684-700 e9. https://doi.org/10.1016/j. ccell.2017.09.014

76. Chen FY, LoTurco J. A method for stable transgenesis of radial glia lineage in rat neocortex by piggyBac mediated transposition. J Neurosci Meth. 2012;207(2):172-80. https://doi.org/10.1016/j. jneumeth.2012.03.016

77. Berube NG, Mangelsdorf M, Jagla M, Vanderluit J, Garrick D, Gibbons RJ, et al. The chromatinremodeling protein ATRX is critical for neuronal survival during corticogenesis. J Clin Invest. 2005;115(2):258-67. https://doi.org/10.1172/JCI200522329

78. Schwartzentruber J, Korshunov A, Liu XY, Jones DTW, Pfaff E, Jacob K, et al. Driver mutations in histone H3.3 and chromatin remodelling genes in paediatric glioblastoma. Nature. 2012;482(7384):226-231.

79. Jiao YC, Killela PJ, Reitman ZJ, Rasheed BA, Heaphy CM, de Wilde RF, et al. Frequent ATRX, CIC, FUBPl and IDHl mutations refine the classification of malignant gliomas. Oncotarget. 2012;3(7):709-22. https://doi.org/10.18632/oncotarget.588

80. Chan KM, Fang D, Gan HY, Hashizume R, Yu CH, Schroeder M, et al. The histone H3.3K27M mutation in pediatric glioma reprograms H3K27 methylation and gene expression. Gene Dev. 2013;27(9):985-90. https://doi.org/10.1101/gad.217778.113

81. Hou XM, Du Y, Deng Y, Wu JF, Cao GW. Sleeping Beauty transposon system for genetic etiological research and gene therapy of cancers. Cancer Biol Ther. 2015;16(1):8-16. https://doi.org/10.4161/15 384047.2014.986944

82. Wang W, Lin CY, Lu D, Ning ZM, Cox T, Melvin D, et al. Chromosomal transposition of PiggyBac in mouse embryonic stem cells. P Natl Acad Sci USA. 2008;105(27):9290-5. https://doi.org/10.1073/ pnas.0801017105

83. Liang Q, Kong J, Stalker J, Bradley A. Chromosomal Mobilization and Reintegration of Sleeping Beauty and PiggyBac Transposons. Genesis. 2009;47(6):404-8. https://doi.org/10.1002/dvg.20508

84. Geurts AM, Yang Y, Clark KJ, Liu GY, Cui ZB, Dupuy AJ, et al. Gene transfer into genomes of human cells by the sleeping beauty transposon system. Mol Ther. 2003;8(1):108-17. https://doi.org/10.1016/ S1525-0016(03)00099-6

85. Lander ES, Consortium IHGS, Linton LM, Birren B, Nusbaum C, Zody MC, et al. Initial sequencing and analysis of the human genome. Nature. 2001;409(6822):860-921. https://doi.org/10.1038/35057062

86. Zhao S, Jiang EZ, Chen SS, Gu Y, Shangguan AJ, Lv TF, et al. PiggyBac transposon vectors: the tools of the human gene encoding. Transl Lung Cancer R. 2016;5(1):120-5.

87. Doudna JA, Charpentier E. The new frontier of genome engineering with CRISPR-Cas9. Science. 2014;346(6213):1077. https://doi.org/10.1126/science.1258096 
88. Hsu PD, Lander ES, Zhang F. Development and Applications of CRISPR-Cas9 for Genome Engineering. Cell. 2014;157(6):1262-78. https://doi.org/10.1016/j.cell.2014.05.010

89. Mali P, Esvelt KM, Church GM. Cas9 as a versatile tool for engineering biology. Nat Methods. 2013;10(10):957-63. https://doi.org/10.1038/nmeth.2649

90. Oldrini B, Curiel-Garcia A, Marques C, Matia V, Uluckan O, Grana-Castro O, et al. Somatic genome editing with the RCAS-TVA-CRISPR-Cas9 system for precision tumor modeling. Nat Commun. 2018;9(1):1466. https://doi.org/10.1038/s41467-018-03731-w

91. Platt RJ, Chen SD, Zhou Y, Yim MJ, Swiech L, Kempton HR, et al. CRISPR-Cas9 Knockin Mice for Genome Editing and Cancer Modeling. Cell. 2014;159(2):440-55. https://doi.org/10.1016/j. cell.2014.09.014

92. Zuckermann M, Hovestadt V, Knobbe-Thomsen CB, Zapatka M, Northcott PA, Schramm K, et al. Somatic CRISPR/Cas9-mediated tumour suppressor disruption enables versatile brain tumour modelling. Nat Commun. 2015;6:7391. https://doi.org/10.1038/ncomms8391

93. Xue W, Chen SD, Yin H, Tammela T, Papagiannakopoulos T, Joshi NS, et al. CRISPR-mediated direct mutation of cancer genes in the mouse liver. Nature. 2014;514(7522):380. https://doi.org/10.1038/ nature 13589

94. Wetmore C, Eberhart DE, Curran T. Loss of p53 but not ARF accelerates medulloblastoma in mice heterozygous for patched. Cancer Res. 2001;61(2):513-6.

95. Zhang XH, Tee LY, Wang XG, Huang QS, Yang SH. Off-target Effects in CRISPR/Cas9-mediated Genome Engineering. Mol Ther Nucleic Acids. 2015;4:e264. https://doi.org/10.1038/mtna.2015.37

96. von Jonquieres G, Mersmann N, Klugmann CB, Harasta AE, Lutz B, Teahan O, et al. Glial Promoter Selectivity following AAV-Delivery to the Immature Brain. Plos One. 2013;8(6):e65646. https://doi. org/10.1371/journal.pone.0065646

97. Hambardzumyan D, Amankulor NM, Helmy KY, Becher OJ, Holland EC. Modeling Adult Gliomas Using RCAS/t-va Technology. Transl Oncol. 2009;2(2):89-95. https://doi.org/10.1593/tlo.09100

98. Niola F, Zhao XD, Singh D, Sullivan R, Castano A, Verrico A, et al. Mesenchymal high-grade glioma is maintained by the ID-RAPl axis (vol 123, pg 405, 2013). J Clin Invest. 2014;124(9):4134. https:// doi.org/10.1172/JCI77927

99. Goncalves A. Use of Retroviral and Lentiviral Vectors to Deliver New Gene Therapies. J Hum Virol Retrovirol. 2017;5(1). https://doi.org/10.15406/jhvrv.2017.05.00140

100. Hu X, Pandolfi PP, Li Y, Koutcher JA, Rosenblum M, Holland EC. mTOR promotes survival and astrocytic characteristics induced by Pten/AKT signaling in glioblastoma. Neoplasia. 2005;7(4):356-68. https://doi.org/10.1593/neo.04595

101. Uhrbom L, Kastemar M, Johansson FK, Westermark B, Holland EC. Cell type-specific tumor suppression by Ink4a and Arf in Kras-induced mouse gliomagenesis. Cancer Res. 2005;65(6):2065-9. https:// doi.org/10.1158/0008-5472.CAN-04-3588

102. Rahme GJ, Luikart BW, Cheng C, Israel MA. A recombinant lentiviral PDGF-driven mouse model of proneural glioblastoma. Neuro-Oncology. 2018;20(3):332-42. https://doi.org/10.1093/neuonc/ nox129

103. Holland EC. A mouse model for glioma: biology, pathology, and therapeutic opportunities. Toxicol Pathol. 2000;28(1):171-7. https://doi.org/10.1177/019262330002800122

104. Holland EC, Celestino J, Dai CK, Schaefer L, Sawaya RE, Fuller GN. Combined activation of Ras and Akt in neural progenitors induces glioblastoma formation in mice. Nat Genet. 2000;25(1):55-7. https://doi.org/10.1038/75596

105. von Werder A, Seidler B, Schmid RM, Schneider G, Saur D. Production of avian retroviruses and tissue-specific somatic retroviral gene transfer in vivo using the RCAS/TVA system. Nat Protoc. 2012;7(6):1167-83. https://doi.org/10.1038/nprot.2012.060

106. Hambardzumyan D, Parada LF, Holland EC, Charest AL. Genetic Modeling of Gliomas in Mice: New Tools to Tackle Old Problems. Glia. 2011;59(8):1155-68. https://doi.org/10.1002/glia.21142

107. Martinez-Lage M, Lynch TM, Bi YT, Cocito C, Way GP, Pal S, et al. Immune landscapes associated with different glioblastoma molecular subtypes. Acta Neuropathol Com. 2019;7(1). https://doi. org/10.1186/s40478-019-0803-6 
108. Chen ZH, Hambardzumyan D. Immune Microenvironment in Glioblastoma Subtypes. Front Immunol. 2018;9:1004. https://doi.org/10.3389/fimmu.2018.01004

109. Malo CS, Huggins MA, Goddery EN, Tolcher HMA, Renner DN, Jin F, et al. Non-equivalent antigen presenting capabilities of dendritic cells and macrophages in generating brain-infiltrating CD8 (+) T cell responses. Nat Commun. 2018;9(1):633. https://doi.org/10.1038/s41467-018-03037-x

110. Huang P, Allam A, Taghian A, Freeman J, Duffy M, Suit HD. Growth and metastatic behavior of five human glioblastomas compared with nine other histological types of human tumor xenografts in SCID mice. J Neurosurg. 1995;83(2):308-15. https://doi.org/10.3171/jns.1995.83.2.0308

111. Hoffmann N, Fernandez V, Pereira RC, Rancati S, Pelizzoli R, Tonelli DD. A Xenotransplant Model of Human Brain Tumors in Wild-Type Mice. Iscience. 2020;23(1):100813. https://doi.org/10.1016/j. isci.2019.100813

112. Renner DN, Malo CS, Jin F, Parney IF, Pavelko KD, Johnson AJ. Improved Treatment Efficacy of Antiangiogenic Therapy when Combined with Picornavirus Vaccination in the GL261 Glioma Model. Neurotherapeutics. 2016;13(1):226-36. https://doi.org/10.1007/s13311-015-0407-1

113. Carlson BL, Pokorny JL, Schroeder MA, Sarkaria JN. Establishment, maintenance and in vitro and in vivo applications of primary human glioblastoma multiforme (GBM) xenograft models for translational biology studies and drug discovery. Curr Protoc Pharmacol. 2011;51(14):1-14. https://doi. org/10.1002/0471141755.ph1416s52

114. Chen F, Becker A, LoTurco J. Overview of Transgenic Glioblastoma and Oligoastrocytoma CNS Models and Their Utility in Drug Discovery. Curr Protoc Pharmacol. 2016;72:14.37.1-14.37.12. https://doi. org/10.1002/0471141755.ph1437s72

115. Tritz ZP, Malo CS, Yokanovich L, Jin F, Hansen MJ, Johnson AJ. Dendritic cell expressed H-2D(b) is required for generating antiviral $\mathrm{CD} 8+\mathrm{T}$ cell responses and blood brain barrier disruption during Theiler's virus infection. J Immunol. 2018;200(Suppl 1):108.17.

116. Newcomb EW, Demaria S, Lukyanov Y, Shao YZ, Schnee T, Kawashima N, et al. The combination of ionizing radiation and peripheral vaccination produces long-term survival of mice bearing established invasive GL261 gliomas. Clin Cancer Res. 2006;12(15):4730-7. https://doi.org/10.1158/1078-0432. CCR-06-0593

117. Choi Y, Lee S, Kim K, Kim SH, Chung YJ, Lee C. Studying cancer immunotherapy using patientderived xenografts (PDXs) in humanized mice. Exp Mol Med. 2018;50(8):1-9. https://doi. org/10.1038/s12276-018-0115-0

118. Hashizume R, Andor N, Ihara Y, Lerner R, Gan HY, Chen XY, et al. Pharmacologic inhibition of histone demethylation as a therapy for pediatric brainstem glioma. Nat Med. 2014;20(12):1394-6. https://doi.org/10.1038/nm.3716

119. Liu F, Hon GC, Villa GR, Turner KM, Ikegami S, Yang HJ, et al. EGFR Mutation Promotes Glioblastoma through Epigenome and Transcription Factor Network Remodeling. Mol Cell. 2015;60(2):307-18. https://doi.org/10.1016/j.molcel.2015.09.002

120. Oh T, Fakurnejad S, Sayegh ET, Clark AJ, Ivan ME, Sun MZ, et al. Immunocompetent murine models for the study of glioblastoma immunotherapy. J Transl Med. 2014;12:107. https://doi. org/10.1186/1479-5876-12-107

121. Serano RD, Pegram CN, Bigner DD. Tumorigenic Cell-Culture Lines from a Spontaneous Vm-Dk Murine Astrocytoma (Sma). Acta Neuropathol. 1980;51(1):53-64. https://doi.org/10.1007/ BF00688850

122. Miller J, Eisele G, Tabatabai G, Aulwurm S, von Kurthy G, Stitz L, et al. Soluble CD70: a novel immunotherapeutic agent for experimental glioblastoma Laboratory investigation. J Neurosurg. 2010;113(2):280-5. https://doi.org/10.3171/2009.11.JNS09901

123. Waldron JS, Yang I, Han S, Tihan T, Sughrue ME, Mills SA, et al. Implications for immunotherapy of tumor-mediated T-cell apoptosis associated with loss of the tumor suppressor PTEN in glioblastoma. J Clin Neurosci. 2010;17(12):1543-7. https://doi.org/10.1016/j.jocn.2010.04.021

124. Marsh J, Mukherjee P, Seyfried TN. Akt-dependent proapoptotic effects of dietary restriction on latestage management of a phosphatase and tensin homologue/tuberous sclerosis complex 2-deficient mouse astrocytoma. Clin Cancer Res. 2008;14(23):7751-62. https://doi.org/10.1158/1078-0432. CCR-08-0213 
125. Hellums EK, Markert JM, Parker JN, He B, Perbal B, Roizman B, et al. Increased efficacy of an interleukin-12-secreting herpes simplex virus in a syngeneic intracranial murine glioma model. Neuro Oncol. 2005;7(3):213-24. https://doi.org/10.1215/S1152851705000074

126. Markert JM, Cody JJ, Parker JN, Coleman JM, Price KH, Kern ER, et al. Preclinical evaluation of a genetically engineered herpes simplex virus expressing interleukin-12. J Virol. 2012;86(9):5304-13. https://doi.org/10.1128/JVI.06998-11

127. Park SD, Kim CH, Kim CK, Park JA, Sohn HJ, Hong YK, et al. Cross-priming by temozolomide enhances antitumor immunity of dendritic cell vaccination in murine brain tumor model. Vaccine. 2007;25(17):3485-91. https://doi.org/10.1016/j.vaccine.2006.12.060

128. Lumniczky K, Desaknai S, Mangel L, Szende B, Hamada H, Hidvegi EJ, et al. Local tumor irradiation augments the antitumor effect of cytokine-producing autologous cancer cell vaccines in a murine glioma model. Cancer Gene Ther. 2002;9(1):44-52. https://doi.org/10.1038/sj.cgt.7700398

129. Szatmari T, Lumniczky K, Desaknai S, Trajcevski S, Hidvegi EJ, Hamada H, et al. Detailed characterization of the mouse glioma 261 tumor model for experimental glioblastoma therapy. Cancer Sci. 2006;97(6):546-53. https://doi.org/10.1111/j.1349-7006.2006.00208.x

130. Ausman JI, Shapiro WR, Rall DP. Studies on the chemotherapy of experimental brain tumors: development of an experimental model. Cancer Res. 1970;30(9):2394-400.

131. Zagzag D, Esencay M, Mendez O, Yee H, Smirnova I, Huang YY, et al. Hypoxia- and vascular endothelial growth factor-induced stromal cell-derived factor-1 alpha/CXCR4 expression in glioblastomas - One plausible explanation of Scherer's structures. Am J Pathol. 2008;173(2):545-60. https://doi. org/10.2353/ajpath.2008.071197

132. Jacobs VL, Valdes PA, Hickey WF, De Leo JA. Current review of in vivo GBM rodent models: emphasis on the CNS-1 tumour model. Asn Neuro. 2011;3(3):e00063. https://doi.org/10.1042/ AN20110014

133. Zeng J, See AP, Phallen J, Jackson CM, Belcaid Z, Ruzevick J, et al. Anti-PD-1 Blockade and Stereotactic Radiation Produce Long-Term Survival in Mice With Intracranial Gliomas. Int J Radiat Oncol. 2013;86(2):343-9. https://doi.org/10.1016/j.ijrobp.2012.12.025

134. Chaudhry IH, O'Donovan DG, Brenchley PEC, Reid H, Roberts ISD. Vascular endothelial growth factor expression correlates with tumour grade and vascularity in gliomas. Histopathology. 2001;39(4):409-15. https://doi.org/10.1046/j.1365-2559.2001.01230.x

135. Lenting K, Verhaak R, Ter Laan M, Wesseling P, Leenders W. Glioma: experimental models and reality. Acta Neuropathol. 2017;133(2):263-82. https://doi.org/10.1007/s00401-017-1671-4

136. Furnari FB, Fenton T, Bachoo RM, Mukasa A, Stommel JM, Stegh A, et al. Malignant astrocytic glioma: genetics, biology, and paths to treatment. Gene Dev. 2007;21(21):2683-710. https://doi.org/10.1101/ gad. 1596707

137. Radaelli E, Ceruti R, Patton V, Russo M, Degrassi A, Croci V, et al. Immunohistopathological and neuroimaging characterization of murine orthotopic xenograft models of glioblastoma multiforme recapitulating the most salient features of human disease. Histol Histopathol. 2009;24(7):879-91.

138. Mathieu V, De Neve N, Le Mercier M, Dewelle J, Gaussin JF, Dehoux M, et al. Combining bevacizumab with temozolomide increases the antitumor efficacy of temozolomide in a human glioblastoma orthotopic xenograft model. Neoplasia. 2008;10(12):1383-92. https://doi.org/10.1593/neo.08928

139. Giannini C, Sarkaria JN, Saito A, Uhm JH, Galanis E, Carlson BL, et al. Patient tumor EGFR and PDGFRA gene amplifications retained in an invasive intracranial xenograft model of glioblastoma multiforme. Neuro Oncol. 2005;7(2):164-76. https://doi.org/10.1215/S1152851704000821

140. Daniel VC, Marchionni L, Hierman JS, Rhodes JT, Devereux WL, Rudin CM, et al. A primary xenograft model of small-cell lung cancer reveals irreversible changes in gene expression imposed by culture in vitro. Cancer Res. 2009;69(8):3364-73. https://doi.org/10.1158/0008-5472.CAN-08-4210

141. De Vleeschouwer S. Glioblastoma. 1st ed. Brisbane, Australia: Codon Pulications; 2017. Chapter 7, mouse models of glioblastoma. Glioblastoma; p131-9. https://doi.org/10.15586/codon.glioblastoma.2017.ch7

142. Huszthy PC, Daphu I, Niclou SP, Stieber D, Nigro JM, Sakariassen PO, et al. In vivo models of primary brain tumors: pitfalls and perspectives. Neuro-Oncology. 2012;14(8):979-93. https://doi. org/10.1093/neuonc/nos135 
143. Mahesparan R, Read TA, Lund-Johansen M, Skaftnesmo KO, Bjerkvig R, Engebraaten O. Expression of extracellular matrix components in a highly infiltrative in vivo glioma model. Acta Neuropathol. 2003;105(1):49-57. https://doi.org/10.1007/s00401-002-0610-0

144. Okada S, Vaeteewoottacharn K, Kariya R. Application of Highly Immunocompromised Mice for the Establishment of Patient-Derived Xenograft (PDX) Models. Cells-Basel. 2019;8(8):889. https://doi. org/10.3390/cells8080889

145. Ono A, Hattori S, Kariya R, Iwanaga S, Taura M, Harada H, et al. Comparative Study of Human Hematopoietic Cell Engraftment into Balb/c and C57BL/6 Strain of Rag-2/Jak3 Double-Deficient Mice. J Biomed Biotechnol. 2011;2011:539748. https://doi.org/10.1155/2011/539748

146. Shultz LD, Lyons BL, Burzenski LM, Gott B, Chen XH, Chaleff S, et al. Human lymphoid and myeloid cell development in NOD/LtSz-scid IL2R gamma(null) mice engrafted with mobilized human hemopoietic stem cells. J Immunol. 2005;174(10):6477-89. https://doi.org/10.4049/ jimmunol.174.10.6477

147. Alonso MM, Gomez-Manzano C, Bekele BN, Yung WKA, Fueyo J. Adenovirus-based strategies overcome temozolomide resistance by silencing the O-6-methylguanine-DNA methyltransferase promoter. Cancer Res. 2007;67(24):11499-504. https://doi.org/10.1158/0008-5472.CAN-07-5312

148. Lee SY. Temozolomide resistance in glioblastoma multiforme. Genes Dis. 2016;3(3):198-210. https:// doi.org/10.1016/j.gendis.2016.04.007

149. Kanzawa T, Germano IM, Komata T, Ito H, Kondo Y, Kondo S. Role of autophagy in temozolomideinduced cytotoxicity for malignant glioma cells. Cell Death Differ. 2004;11(4):448-57. https://doi. org/10.1038/sj.cdd.4401359

150. Le Calve B, Rynkowski M, Le Mercier M, Bruyere C, Lonez C, Gras T, et al. Long-term in vitro treatment of human glioblastoma cells with temozolomide increases resistance in vivo through upregulation of GLUT transporter and aldo-keto reductase enzyme AKRIC expression. Neoplasia. 2010;12(9):727-39.

151. Hegi ME, Diserens A, Gorlia T, Hamou M, de Tribolet N, Weller M, et al. MGMT gene silencing and benefit from temozolomide in glioblastoma. New Engl J Med. 2005;352(10):997-1003. https://doi. org/10.1056/NEJMoa043331

152. Mathieu V, Neve N, Le Mercier M, Dewelle J, Gaussin JF, Dehoux M, et al. Combining Bevacizumab with Temozolomide Increases the Antitumor Efficacy of Temozolomide in a Human Glioblastoma Orthotopic Xenograft Model. Neoplasia. 2008;10(12):1383-92. https://doi.org/10.1593/neo.08928

153. Ben-David U, Ha G, Tseng YY, Greenwald NF, Oh C, Shih J, et al. Patient-derived xenografts undergo mouse-specific tumor evolution. Nat Genet. 2017;49(11):1567-75. https://doi.org/10.1038/ng.3967

154. deCarvalho AC, Kim H, Poisson LM, Winn ME, Mueller C, Cherba D, et al. Discordant inheritance of chromosomal and extrachromosomal DNA elements contributes to dynamic disease evolution in glioblastoma. Nat Genet. 2018;50(5):708-17. https://doi.org/10.1038/s41588-018-0105-0

155. Allen TM, Brehm MA, Bridges S, Ferguson S, Kumar P, Mirochnitchenko O, et al. Humanized immune system mouse models: progress, challenges and opportunities. Nat Immunol. 2019;20(7):770-4. https://doi.org/10.1038/s41590-019-0416-z

156. Meraz IM, Majidi M, Meng F, Shao RP, Ha MJ, Neri S, et al. An Improved Patient-Derived Xenograft Humanized Mouse Model for Evaluation of Lung Cancer Immune Responses. Cancer Immunol Res. 2019;7(8):1267-79. https://doi.org/10.1158/2326-6066.CIR-18-0874

157. Meraz IM, Majidi M, Meng F, Shao RP, Ha MJ, Neri S, et al. Development of an improved humanized patient-derived xenograft, Hu-PDX, mouse model for evaluation of antitumor immune response in lung cancer. Cancer Res. 2019;79(13). https://doi.org/10.1158/1538-7445.SABCS18-4984

158. Yao LC, Aryee KE, Cheng M, Kaur P, Keck JG, Brehm MA. Creation of PDX-Bearing Humanized Mice to Study Immuno-oncology. Methods Mol Biol. 2019;1953:241-52. https://doi. org/10.1007/978-1-4939-9145-7_15

159. Magnotti E, Marasco WA. The latest animal models of ovarian cancer for novel drug discovery. Expert Opin Drug Dis. 2018;13(3):249-57. https://doi.org/10.1080/17460441.2018.1426567

160. McIntosh BE, Brown ME, Duffin BM, Maufort JP, Vereide DT, Slukvin II, et al. Nonirradiated NOD,B6. SCID Il2r gamma(-/-) Kit(W41/W41) (NBSGW) Mice Support Multilineage Engraftment of Human Hematopoietic Cells. Stem Cell Rep. 2015;4(2):171-80. https://doi.org/10.1016/j.stemcr.2014.12.005 
161. Herndler-Brandstetter D, Shan L, Yao Y, Stecher C, Plajer V, Lietzenmayer M, et al. Humanized mouse model supports development, function, and tissue residency of human natural killer cells. Proc Natl Acad Sci USA. 2017;114(45):E9626-E34. https://doi.org/10.1073/pnas.1705301114

162. Ashizawa T, lizuka A, Nonomura C, Kondou R, Maeda C, Miyata H, et al. Antitumor Effect of Programmed Death-1 (PD-1) Blockade in Humanized the NOG-MHC Double Knockout Mouse. Clin Cancer Res. 2017;23(1):149-58. https://doi.org/10.1158/1078-0432.CCR-16-0122

163. Zhai LJ, Ladomersky E, Lauing KL, Wu MJ, Genet M, Gritsina G, et al. Infiltrating T Cells Increase IDO1 Expression in Glioblastoma and Contribute to Decreased Patient Survival. Clin Cancer Res. 2017;23(21):6650-60. https://doi.org/10.1158/1078-0432.CCR-17-0120

164. Dees K, Koo H, Hakim J, Humphreys JF, Crossman D, Crowley M, et al. Elucidating the Resistance to Immunotherapy in Brain Tumors Using a Humanized Microbiome Mouse Model. Neuro-Oncology. 2019;21(Suppl 6):vi266. https://doi.org/10.1093/neuonc/noz175.1118

165. McFarland B, Dees K, Little R, Van Der Pol W, Benveniste E, Morrow C, et al. Humanized Microbiome Mouse Models to Enhance Immunotherapy in Glioblastoma. Neuro-Oncology. 2018;20(Suppl 6):vi274. https://doi.org/10.1093/neuonc/noyl48.1139

166. Marchesi JR, Adams DH, Fava F, Hermes GDA, Hirschfield GM, Hold G, et al. The gut microbiota and host health: a new clinical frontier. Gut. 2016;65(2):330-9. https://doi.org/10.1136/ gutjnl-2015-309990

167. Roy S, Trinchieri G. Microbiota: a key orchestrator of cancer therapy. Nat Rev Cancer. 2017;17(5):271-85. https://doi.org/10.1038/nrc.2017.13

168. Hugenholtz F, de Vos WM. Mouse models for human intestinal microbiota research: a critical evaluation. Cell Mol Life Sci. 2018;75(1):149-60. https://doi.org/10.1007/s00018-017-2693-8

169. Arrieta MC, Walter J, Finlay BB. Human Microbiota-Associated Mice: A Model with Challenges. Cell Host Microbe. 2016;19(5):575-8. https://doi.org/10.1016/j.chom.2016.04.014

170. Brehm MA, Shultz LD, Luban J, Greiner DL. Overcoming Current Limitations in Humanized Mouse Research. J Infect Dis. 2013;208:S125-S30. https://doi.org/10.1093/infdis/jit319

171. Wrzosek L, Ciocan D, Borentain P, Spatz M, Puchois V, Hogot C, et al. Transplantation of human microbiota into conventional mice durably reshapes the gut microbiota. Sci Rep. 2018;8:6854. https://doi.org/10.1038/s41598-018-25300-3

172. Sampson JH, Ashley DM, Archer GE, Fuchs HE, Dranoff G, Hale LP, et al. Characterization of a spontaneous murine astrocytoma and abrogation of its tumorigenicity by cytokine secretion. Neurosurgery. 1997;41(6):1365-72. https://doi.org/10.1097/00006123-199712000-00024

173. Wu A, Wiesner S, Xiao J, Ericson K, Chen W, Hall WA, et al. Expression of MHC I and NK ligands on human CD133+ glioma cells: possible targets of immunotherapy. J Neurooncol. 2007;83(2):121-31. https://doi.org/10.1007/s1 1060-006-9265-3

174. Lichtor T, Glick RP, Kim TS, Hand R, Cohen EP. Prolonged survival of mice with glioma injected intracerebrally with double cytokine-secreting cells. J Neurosurg. 1995;83(6):1038-44. https://doi. org/10.3171/jns.1995.83.6.1038

175. Paul AK, Ciesielski MJ, Sajjad M, Wang X, Ferrone S, Abdel-Nabi H, et al. Expression of HMP/AN2, a melanoma associated antigen, in murine cerebral gliomas: potential for radioimmunotargeting. J Neurooncol. 2009;94(1):21-30. https://doi.org/10.1007/s11060-009-9798-3

176. Maes W, Rosas GG, Verbinnen B, Boon L, De Vleeschouwer S, Ceuppens JL, et al. DC vaccination with anti-CD25 treatment leads to long-term immunity against experimental glioma. Neuro Oncol. 2009;11(5):529-42. https://doi.org/10.1215/15228517-2009-004

177. Prins RM, Odesa SK, Liau LM. Immunotherapeutic targeting of shared melanoma-associated antigens in a murine glioma model. Cancer Res. 2003;63(23):8487-91.

178. Kim CH, Hong MJ, Park SD, Kim CK, Park MY, Sohn HJ, et al. Enhancement of anti-tumor immunity specific to murine glioma by vaccination with tumor cell lysate-pulsed dendritic cells engineered to produce interleukin-12. Cancer Immunol Immunother. 2006;55(11):1309-19. https://doi. org/10.1007/s00262-006-0134-x 
